\title{
DINAMIKA PENDIDIKAN KEWIRAUSAHAAN: PEMETAAN SISTEMATIS TERHADAP PENDIDIKAN, PENGAJARAN, DAN PEMBELAJARAN
}

\section{Margo Purnomo}

Fakultas Ilmu Sosial dan Ilmu Politik, Universitas Padjadjaran, Bandung, Indonesia

\begin{tabular}{l} 
Info Artikel \\
\hline Sejarah Artikel: \\
Diterima Januari 2015 \\
Disetujui Februari 2015 \\
Diterbitkan Maret 2015 \\
\hline Keywords: \\
Entrepreneurship Education; \\
Entrepreneurship Teaching; \\
Entrepreneurship Learning; \\
Systematic Review \\
\hline
\end{tabular}

\begin{abstract}
Abstrak
Saat ini belum ada kesepakatan diantara para ahli pendidikan kewirausahaan (PK) tentang pendekatan terbaik dalam pembelajaran (BK) dan pengajaran (AK) kewirausahaan. Berdasarkan Systematic Mapping Study (SMS), ada empat fokus tema dalam PK yaitu kebijakan untuk pendidikan kewirausahaan, konteks pendidikan kewirausahaan, pengajaran kewirausahaan, dan pembelajaran kewirausahaan. Berdasarkan SMS diketahui juga bahwa permasalahannya bukan tentang metode apa yang terbaik dalam PK tetapi pengajar kewirausahaan dituntut untuk mampu mengenali fungsi dan keunggulan setiap metode pengajaran kewirausahaan. Hal ini mengindikasikan bahwa perkembangan kewirausahaan yang semakin kontekstual membutuhkan dukungan kebijakan PK yang terintegrasi baik pada ranah makro, mezzo, dan mikro. Dukungan demikian sangat penting agar pelaksanaan pembelajaran dan pengajaran kewirausahaan yang inovatif, efektif, dan efisien dapat diselenggarakan.
\end{abstract}

\begin{abstract}
Currently there is no agreement among experts in entrepreneurship education about the best approach in learning and teaching entrepreneurship. The development of entrepreneurship study is expanding, and the concept of entrepreneurship is not limited to business people. Consequently, a good approach to entrepreneurship education depends on the purpose and context. Based on the Systematic Mapping Study (SMS), there are four focus themes in entrepreneurship education, namely policy for entrepreneurship education, entrepreneurship education context, teaching entrepreneurship and entrepreneurial learning. Based on SMS also known that the problem is not about what is the best method in entrepreneurship education but teacher who teaching of entrepreneurship is required to recognize the functions and advantages of each entrepreneurship teaching method. The challenge of improving entrepreneurship education quality is not just to develop quality of teaching methods but it will be effective if supported by political legitimacy. This indicates that the expanding on entrepreneurship need an integrated policy support from macro, mezzo, and micro level. Integrated policy is very important to support the implementation of innovative, effective, and efficient entrepreneurship learning and teaching.
\end{abstract}

JEL Classification: G1, G11

\footnotetext{
Alamat korespondensi :

Jalan Bukit Dago Utara No. 25 Bandung 


\section{PENDAHULUAN}

Entrepreneurship merupakan fenomena modern. Kemajuan, ketahanan, dan daya saing sebuah negara pada era global ditentukan oleh jumlah entrepreneur yang dimiliki oleh negara tersebut. Ini menyebakan peran PK saat ini semakin strategis. Penelitian PK terbaru menunjukkan bahwa PK berperan strategis dalam hal pemberdayaan pemuda (AjaOkorie \& Adali, 2013), pembangunan daerah rural (Patel \& Chavda, 2013), wilayah urban (Woolthuis et al., 2013), pembangunan regional (Muller, 2013), pertumbuhan ekonomi (Braunerhjelm, 2010), pemberdayaan disabilities people (WEDC, 2011), dan pemberdayaan wanita (Kalyani \& Kumar, 2011; Lakshmi \& Rangarajan, 2012).

Hasil kajian beberapa ahli ini, sejalan dengan fenomena yang tumbuh di Indonesia diberbagai level pendidikan yang ditawarkan, yang memasukkan atau mencantumkan pendidikan kewirausahaan dalam setiap kurikulum pendidikannya, dengan harapan agar setiap lulusan memiliki bekal enterepreneurship atau berjiwa entrepreneurial. Para lulusan ini diharapkan menjadi sumber daya manusia yang mampu survive (Katz, 2003) dan memiliki daya saing dalam lingkungan global yang kompetitif dan turbulen di era ekonomi pengetahuan (Kuratko, 2003 \& Teece, 2012).

Meningkatnya kesadaran akan pentingnya PK di Indonesia mendorong aneka inovasi dalam penyelenggaraannya (Sudarmanto, 2011; Priyanto, 2012; Mansyur, 2013 \& Susilowati, 2013). Walaupun perhatiannya meningkat, namun PK di Indonesia masih dinilai kurang efektif, dengan indikasi rendahnya minat berwirausaha para lulusan sekolah menengah (Lutfiadi \& Rahmanto, 2011) dan perguruan tinggi (Kurnianto \& Putra, 2012; Mopangga, 2014), motivasi berwirausaha (Seno, 2010), dan jumlah wirausahawan di Indonesia (Priyanto, 2012). juga menjelaskan bahwa minat berwirausaha lulusan lembaga pendidikan sangat rendah, yaitu 22,63\% untuk SLTA dan $6,14 \%$ untuk lulusan perguruan tinggi.
Menyikapi hal tersebut, ada upaya baik dan menarik yang digagas yaitu mengumpulkan para pendidik kewirausahaan di Indonesia dalam sebuah pertemuan yang disebut Roundtable Entrepreneur Educator (REE). Ini merupakan salah satu upaya untuk membangun pemahaman bersama tentang PK di Indonesia. REE ke 2 yang diselenggarakan di Surabaya, Jawa Timur, pada Juni 2014 lalu, Penulis mencoba melakukan pengamatan terhadap proses acara dan wawancara tentang PK pada sembilan pendidik kewirausahaan dengan hasil sebagai berikut: Pertama, adanya kesadaran bersama tentang pentingnya memberikan PK di berbagai bidang lembaga pendidikan dan jenjang pendidikan. Ini nampak dari heterogennya peserta yang hadir dan Penulis wawancarai. Seperti dari bidang keperawatan dan kebidanan, lembaga swadaya masyarakat (LSM), pelaksana corporate social responsibility (CSR) perusahaan, bidang pariwisata, ilmu sosial dan ilmu politik, serta perpajakan.

Kedua, adanya kebingungan tentang bagaimana merancang $\mathrm{PK}$, khususnya pada lembaga pendidikan non ekonomi dan bisnis atau LSM. Beberapa penyebab kebingungan tersebut diantaranya adalah: (a) pandangan sempit bahwa kewirausahaan adalah berbisnis dan berorientasi pada ekonomi semata. Dengan pandangan ini akhirnya para pendidik kewirausahaan non ekonomi dan bisnis memaksakan dirimenyelenggarakan pendidikan kewirausahaan dalam konteks bisnis. Misalnya menugaskan peserta didik non ekonomi dan bisnis berdagang atau membuat business plan. Ini menyebabkan para pendidik kewirausahaan dengan bidang studi non ekonomi dan bisnis merasa melakukan dosa akademik, (b) perbedaan pandangan tentang output PK antara pembuat kebijakan (Departemen Pendidikan dan Kebudayaan) dan pelaksana kebijakan (lembaga pendidikan dan pendidik kewirausahaan). Banyak pendidik yang berharap bahwa setelah peserta didik mengikuti PK maka peserta didik mampu dan siap menjadi pengusaha. Sementara salah satu narasumber dari DIKTI menyatakan bahwa ouput PK 
Margo Purnomo / Dinamika Pendidikan Kewirausahaan: Pemetaan Sistematis Terhadap...

adalah membangun jiwa kewirausahaan, (c) pendidik merasa kurang memperoleh rujukan buku teks tentang perkembangan kontemporer PK khususnya di Indonesia. Walaupun demikian, para pendidik menyadari bahwa kewirausahaan berkembang semakin kontekstual sehingga menuntut pendidik atau pengelola lembaga pendidikan untuk lebih kontekstual juga dalam menyelanggarakan PK dan (d) kurangnya penelitian efektivitas PK. Ini menyebabkan para pendidik kurang memiliki rujukan untuk melakukan evaluasi dan pengendalian proses PK yang telah dilakukan. Karena itu keberhasilan satu dua orang peserta didik dalam berbisnis atau membuat perusahaan sering menjadi justifikasi keberhasilan pendidik kewirausahaan dalam mengajar, walaupun bisnis atau perusahaan peserta didik berbeda dengan latar belakang bidang keilmuannya.

Ketiga, ada kecenderungan bahwa umumnya keberhasilan berwirausaha difahami sebagai keberhasilan membangun perusahaan. Pemahaman ini berdampak pada indikator kesuksesan seorang wirausahawan umumnya dilihat dari aspek keuangan, pemasaran, operasi, atau sumber daya manusia. Misalnya perkembangan aset, daya laba, jumlah pegawai, dan capaian market share. Informasi tersebut sering menjadi media untuk memprofokasi peserta didik berwirausaha. Padahal secara teoritis, keberhasilan berwirausaha adalah keberhasilan mengidentifikasi peluang dan melakukan venture.

Keempat, pengelolaan PK belum memiliki action plan yang disepakati bersama. Dampaknya adalah PK cenderung tidak strategis, berjalan sendiri-sendiri, tidak konsisten, dan dukungan yang rendah dari para stakeholder. Pada era otonomi saat ini setiap pendidik kewirausahaan juga diberikan otonomi untuk mengembangkan model PK. Namun karena alasan keterbatasan, rancangan model PK umumnya sekedar formalitas dan belum memperhatikan karakteristik dan potensi sumber daya lokal, demografis, dan geografis. Akibatnya, lulusan sekolah atau universitas tidak 'mengimani' adanya peluang pada korelasi antara potensi ilmu yang dipelajarinya dengan potensi sumber daya di wilayah tempat tinggalnya.

Fenomena di atas merupakan indikasi bahwa sementara ini PK umumnya masih merupakan isolated island (Todorov \& Papazov, 2009; Purnomo, 2014). Penulis juga memperhatikan fenomena PK yang heterogen. Hal ini sesuai dengan pendapat Schultz yang telah menyarankan sejak tahun 1975 agar konsep entrepreneurship tidak terbatas untuk orang-orang bisnis semata (Kuip \& Verheul, 2003). Fenomena tersebut juga menjadi latar belakang yang mendasari Penulis untuk berusaha melakukan penelitian terhadap berbagai pustaka yang berhubungan dengan PK dalam rangka menjawab permasalahan tentangarea apa saja yang ada dalam pendidikan kewirausahaan?area apa saja yang ada dalam pengajaran kewirausahaan? Area apa saja yang ada dalam pembelajaran kewirausahaan? dan berapa banyak artikel yang tercakup dalam setiap area?.

Menjawab permasalahan itu Penulis dalam paper ini melakukan penelitian dengan systematic mapping study (Petersen et al., 2009). Systematic mapping study (SMS) sendiri merupakan bagian dari systematic literature review (SLR) karena SMS merupakan tahap awal sebelum melakukan SLR (Kitchenham \& Charters, 2007; Petersen et al., 2009). Menggunakan SLR dalam kewirausahaan merupakan pendekatan yang cocok untuk penelitian kewirausahaan (Pittaway \& Cope, 2006; Henry et al., 2013).

Menggunakan SMS juga sesuai tujuan artikel ini yaitu memetakan dan mengelompokkan publikasi ilmiah dibidang PK sehingga dapat diperoleh gambaran tentang PK sampai dengan saat ini. SMS memberikan keleluasaan bagi Peneliti untuk melibatkan berbagai pustaka sesuai dengan fokus tema penelitian yang dilakukan (Petersen et al., 2009). Dengan demikian temuan dalam artikel ini diharapkan dapat menjadi initial research untuk ditindaklanjuti dengan tahap SLR selanjutnya atau penelitian lapangan tentang PK 
di Indonesia serta memberikan arahan kedepan dan merangsang ide untuk mengembangkan kualitas PK di Indonesia.

\section{Pendidikan Kewirausahaan}

Hasil penelitian Fayolle et all. (2006) mendefinisikan PK sebagai:

"any pedagogical programme or process of education for entrepreneurial attitudes and skills, which involves developing certain personal qualities". Selanjutnya menurut The Organization for Economic Cooperation and Development (OECD, 2009) menyatakan bahwa Entrepreneurship education is the application of enterprise skills specifically to the creation and growth of organisations, with entrepreneurship education focusing on developing skills and applying an enterprising mindset in the specific contexts of setting up a new venture, developing and growing an existing business, or designing an entrepreneurial organization."

Berdasarkan kedua pengertian pengertian tersebut nampak bahwa PK tidak diartikan sempit sebagai pendidikan dalam konteks menciptakan perusahaan baru, atau berbisnis.

Pengertian tersebut selaras dengan penegasan Sarasvathy dan Venkataraman (2011) yang menyatakan bahwa kewirusahaan merupakan fenomena yang sangat heterogen. Perkembangan kewirausahaan sendiri saat ini semakin kontekstual. Hal ini diindikasikan dengan munculnya berbagai konsep baru kewirausahaan yang spesifik pada bidangbidang tertentu seperti women entrepreneurship, social entrepreneurship (Brock \& ASHOKA, 2008), technopreneurship, rural entrepreneurship, urban entrepreneurship, minority entrepreneurship, ecopreneurship (Purnomo, 2014) dan bahkan lebih spesifik lagi seperti rural women entrepreneurship (Onwurafor \& Enwelu, 2013) dan ecotourism entrepreneurship (Asadi \& Kohan, 2011). Setiap bidang tersebut tentunya akan menuntut konten PK yang berbeda karena kewirausahaan pada setiap bidang tersebut tentunya memiliki pengetahuan dan keterampilan yang khas sehingga menuntut desain PK yang berbeda. Contoh kondisi tersebut adalah buku karya Brock dan ASHOKA (2008) tentang Social Entrepreneurship: Teaching Resources Handbook, yaitu buku pegangan khusus bagi pengajar kewirausahaan di bidang kewirausahaan sosial.

Konsep kewirausahaan yang semakin meluas menunjukkan bahwa kewirausahaan bukan monopoli lembaga pendidikan ekonomi, bisnis, atau manajemen. Penelitian Lindner (2012) dalam konteks filsafat pendidikan ekonomi menyatakan bahwa pendidikan kewirausahaan dibutuhkan karena "society needs a culture of independence and responsibility". Oleh sebab itu wirausahawan menurut Lindner (2012) adalah pribadi-pribadi

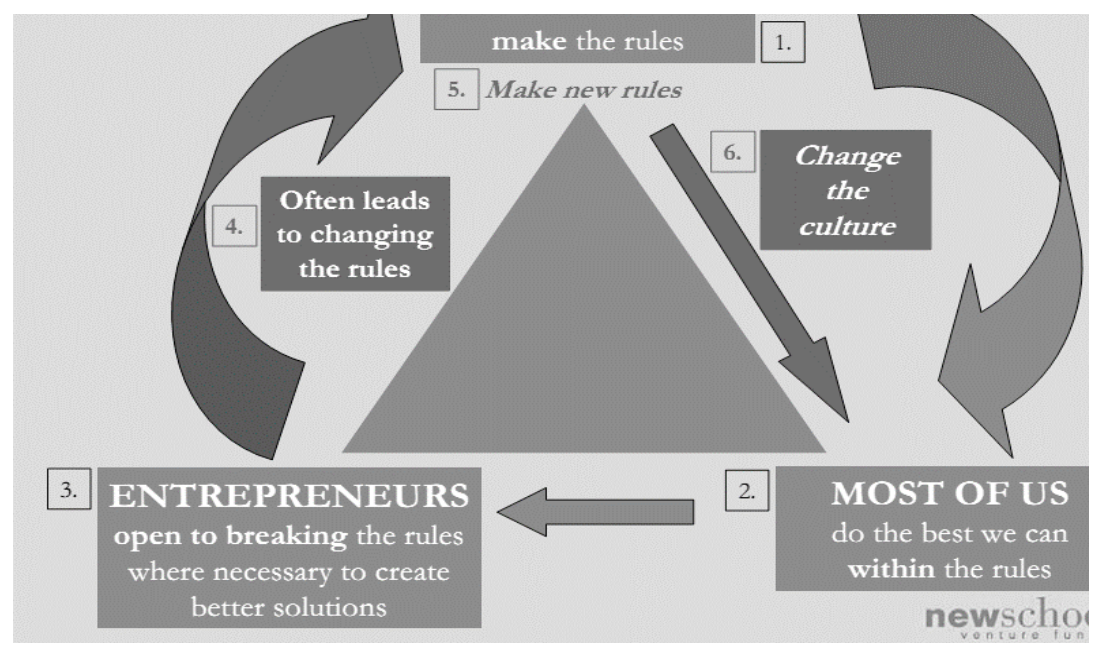

Sumber: Smith \& Petersen (2006)

Gambar 1. Peran Sosial Wirausahawan 
Margo Purnomo / Dinamika Pendidikan Kewirausahaan: Pemetaan Sistematis Terhadap...

dinamis (dynamic person) yang membuat perekonomian dan masyarakat terus bergerak. Perkembangan demikian membuat PK membutuhkan dukungan kebijakan sejak di tingkat pemerintahan pusat sampai dengan pelaksana di kelas-kelas kewirausahaan guna menjaga ketersediaan para dynamic persons tersebut. Secara ringkas Smith \& Petersen (2006) membuat siklus peran wirausahawan, pembuat kebijakan, dan masyarakat seperti pada Gambar 1.

Berdasarkan penjelasan-penjelasan di atas maka dapat diambil proposisi sebagai berikut:

Proposisi 1: Pelaksanaan PK membutuhkan dukungan kebijakan dari pemerintah, lembaga pengelola, dan pelaksana PK di kelas-kelas kewirausahaan

Proposisi 2: PKmemiliki bentukyang heterogen tergantung konteks pelaksanaan PK.

Selanjutnya, kunci keberhasilan PK menurut Arasti et al. (2012) adalah untuk menemukan cara yang paling efektif untuk mengelola keterampilan mendidik dan mengidentifikasi perpaduan terbaik antara kebutuhan siswa dan teknik pengajaran, karena itu, dalam kajian pustaka ini diulas juga tentang pengajaran (AK) dan pembelajaran kewirausahaan (BK).

\section{Pengajaran Kewirausahaan}

Hasil penelitian Albornoz \& Rocco (2009) berpandangan bahwa cara paling menjanjikan memperbaiki PK adalah memperbaiki pengajaran kewirausahaan (AK). AK adalah

"the process of providing individuals with the concepts and skills to recognize opportunities that others have overlooked and to have the insight, self-esteem, and knowledge to act where others have hesitated"

Berdasarkan pengertian tersebut, AK sebaiknya mampu memicu inspirasi, membangkitkan emosi, dan merubah pola pikir peserta belajar. Oleh sebab itu para ahli mengkritisi penggunaan desain pedagogis konvensional yang cenderung teacher centered. Kalaupun tetap menjalankan desain pedagogi konvensional Klapper (2010) merekomendasikan untuk menggunakan innovative pedagogy, atau pendapat Tasnim dan Yahya (2013) yaitu active pedagogy.

Upaya yang baik dan menarik dilakukan oleh Lackeus et al. (2013) yang berusaha membuat kerangka kerja tentang dualisme pengajaran kewirausahaan seperti pada Gambar 2. Gambar 2 merupakan panduan menyusun kurikulum yang menjembatani antara teori pendidikan dan kewirausahaan. Penelitian Onojetah \& Amiaya (2013) mengusulkan pendekatan baru pada kurikulum kewirausahaan, yaitu The Multiple Contexts of Entrepreneurship Education/Studies Curriculum and Instruction. Pendekatan ini berusaha mengikuti perkembangan kewirausahaan yang semakin kontekstual. Berdasarkan penjelasanpenjelasan di atas maka dapat diambil proposisi sebagai berikut:

Proposisi 3: Pelaksanaan AK dilakukan secara kontekstual dan pengajar berperan memfasilitasi.

\section{Pembelajaran Kewirausahaan}

Pembelajaran kewirausahaan (BK) didefinisikan oleh Rae dan Carswell (2000) sebagai proses pemecahan masalah yang berpusat pada akuisisi, penyimpanan dan penggunaan pengetahuan kewirausahaan dalam memori jangka panjang. Walau demikian, BK umumnya disederhanakan sebagai belajar bagaimana mengenali kesempatan (Rae, 2003; Lumpkin \& Lichtenstein, 2005). Penelitian Rae (2003) mengusulkan bahwa fokus BK adalah mengenali kesempatan, dengan alasan bahwa identifikasi kesempatan adalah tindakan belajar itu sendiri dan sumber motivasi untuk belajar kewirausahaan. Output PK idealnya adalah kemampuan mengidentifikasi adanya peluang atau mengidentifikasi ide yang baik dan mengubahnya menjadi sebuah konsep bernilai tambah (Lumpkin \& Lichtenstein, 2005). 
Jurnal Dinamika Manajemen Vol. 6, No. 1, 2015, pp: 97-120

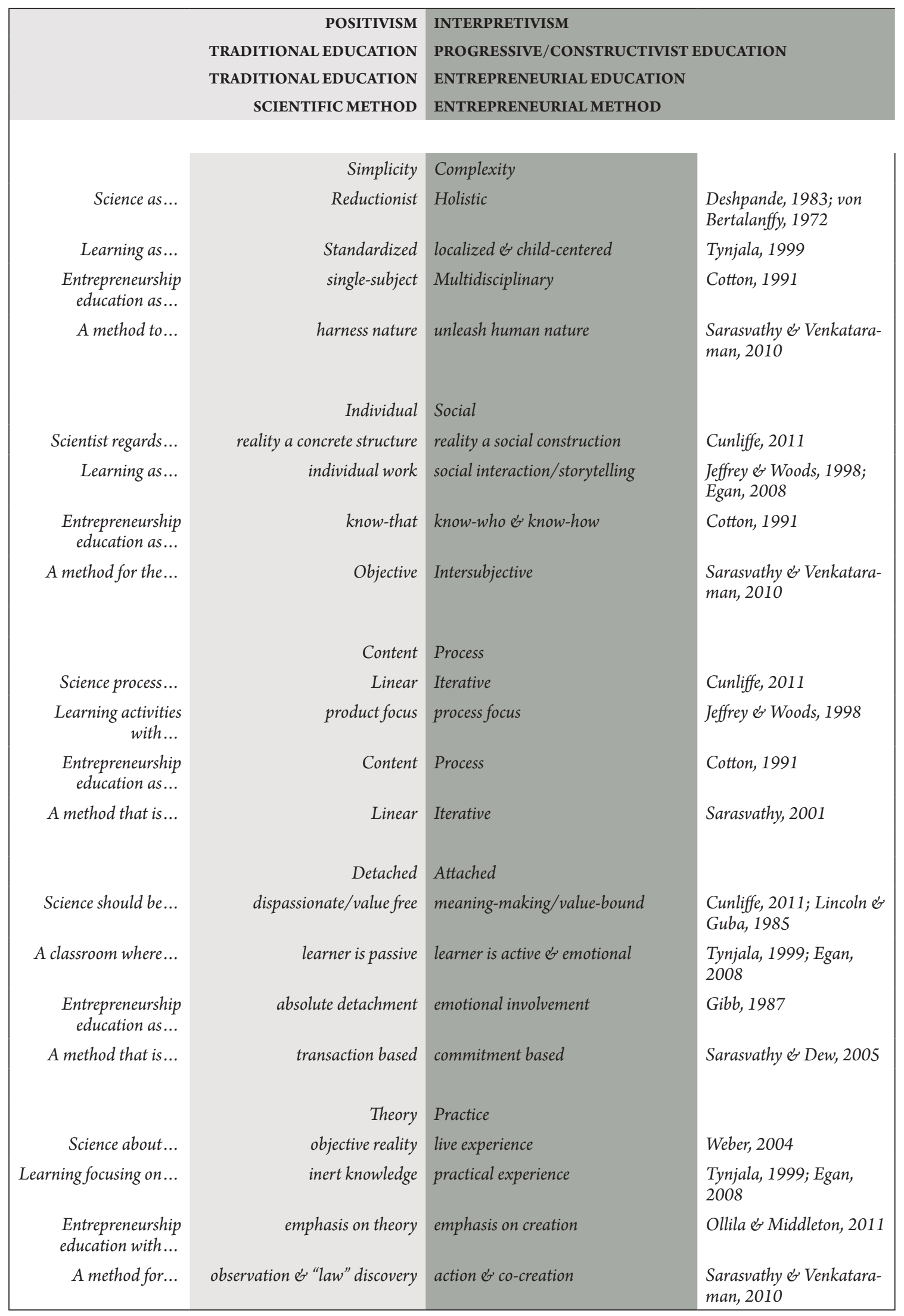

Gambar 2. Dualisme Pengajaran Kewirausahaan

Sumber: Lackeus et al. (2013) 
Margo Purnomo / Dinamika Pendidikan Kewirausahaan: Pemetaan Sistematis Terhadap...

Pembelajaran kewirausahaan seperti halnya bidang studi lain telah diselenggarakan dengan menggunakan berbagai teori pembelajaran. Efektivitasnya menantang para pelaksana PK untuk terus mengembangkan pendekatan terhadap BK. Hal ini seperti pendapat Garavan \& Cinneide (1994) yang berkata bahwa sampai saat ini kita tidak tahu bagaimana wirausahawan belajar. Para penulis merekomendasikan agar dalam BK peserta di ajak langsung ke lapangan dan merasakan langsung berwirausaha. Selain itu, hampir semua penulis konsisten mengkritisi penggunaan desain pedagogis yang cenderung pasive learning dan merekomendasikan active learning seperti kompetensi (Man, 2006 \& Mulder et al., 2007), co-participation (Taylor \& Thorpe, 2004), kontingensi (Honig, 2004), problem based learning (Tan \& Ng, 2006), dan action learning (Taylor et al., 2004). Pendekatan-pendekatan tersebut memposisikan peserta sebagai subyek, dan pengajar sebagai fasilitator atau menurut Lourenco dan Jones (2006) bersifat bottom-up constructive. Berdasarkan penjelasan-penjelasan di atas maka dapat diambil proposisi sebagai berikut:

Proposisi 4: Pelaksanaan BK dilakukan dengan pendekatan-pendekatan inovatif.

\section{METODE}

Metode penelitian dalam paper ini adalah SMS. SMS termasuk ke dalam SLR karena merupakan tahap awal sebelum melakukan SLR (Kitchenham \& Charters, 2007; Petersen et a., 2009). Ada dua argumen yang melandasi dilakukannya SLR dalam paper ini. Pertama, pendapat Pittaway et al. (2008) yang menyatakan bahwa SLR dalam penelitian kewirausahaan berguna untuk mengurangi fragmentasi. Ini dapat dilakukan dengan cara membedakan atau menghubungkan pustaka kewirausahaan, membuat generalisasi kerangka tematis tertentu, serta membuat arahan baru untuk penelitian empiris kewirausahaan (Pittaway et al., 2008). Kedua, pendapat Hindle

Tabel 1. Perbedaan SMS dengan SLR

\begin{tabular}{|c|c|c|c|}
\hline No & Keterangan & SMS & SLR \\
\hline 1 & Tujuan & $\begin{array}{l}\text { Melakukan pemetaan, } \\
\text { pengelompokkan, analisa tematis, } \\
\text { dan mengidentifikasi publikasi } \\
\text { Tahap awal dalam melakukan SLR }\end{array}$ & $\begin{array}{l}\text { Melakukan identifikasi best practice } \\
\text { berdasarkan bukti empiris secara detail } \\
\text { Tindak lanjut hasil SMS dengan } \\
\text { memilih tema tertentu hasil analisa } \\
\text { tematis dalam SMS }\end{array}$ \\
\hline & $\begin{array}{l}\text { Pertanyaan } \\
\text { penelitian }\end{array}$ & Lebih l & Lebih sempit dan spesifik \\
\hline 2 & $\begin{array}{l}\text { Kelebihan/ } \\
\text { Kelemahan }\end{array}$ & $\begin{array}{l}\text { Tidak mampu menunjukkan missing } \\
\text { atau insufficient evidence dalam studi } \\
\text { yang telah ada } \\
\text { Lebih umum }\end{array}$ & $\begin{array}{l}\text { Mampu menunjukkan missing atau } \\
\text { insufficient evidence dalam studi yang } \\
\text { telah ada } \\
\text { Lebih detail }\end{array}$ \\
\hline 3 & $\begin{array}{l}\text { Metode } \\
\text { Ekstraksi } \\
\text { data }\end{array}$ & $\begin{array}{l}\text { Thematic analysis } \\
\text { Tidak melakukan evaluasi terhadap } \\
\text { kualitas artikel karya ilmiah }\end{array}$ & $\begin{array}{l}\text { Meta analysis } \\
\text { Melakukan evaluasi kualitas artikel } \\
\text { karya ilmiah }\end{array}$ \\
\hline 4 & Analisa data & $\begin{array}{l}\text { Membuat ringkasan dan } \\
\text { pengelompokkan data untuk } \\
\text { menjawab pertanyaan penelitian }\end{array}$ & $\begin{array}{l}\text { Melibatkan in depth analysis technique } \\
\text { seperti meta-analysis atau narrative } \\
\text { synthesis }\end{array}$ \\
\hline
\end{tabular}

Sumber: Kitchenham \& Charters (2007) dan Petersen et al. (2009) 
(2007) yang mengemukakan bahwa dalam konteks PK, banyak sekali inovasi pendidikan yang telah dilakukan oleh para pendidik maupun lembaga pendidikan. Hal ini bagus namun kita perlu mengetahui konsistensi dari setiap inovasi PK yang telah dilakukan. Karena itu, SLR merupakan pendekatan yang cocok untuk penelitian kewirausahaan (Pittaway \& Cope, 2006; Henry et al., 2013).

SLR sendiri menurut Thorpe et al. (2005) sebaiknya memenuhi prinsip dasar SLR, yaitu transparan, jelas, fokus dan seragam. Guna memenuhi prinsip tersebut maka perlu melakukan SMS karena SMS dalam SLR membantu menghasilkan pemetaan dan pengelompokkan tema-tema yang berguna untuk penelitian selanjutnya (Kitchenham \& Charters, 2007; Petersen et al., 2009). Walaupun merupakan bagian dari SLR, Kitchenham dan Charters (2007) dan Petersen et al. (2009) memberikan perbedaan SMS dengan SLR seperti pada Tabel 1. Adapun tahap SMS dalam artikel ini dilakukan berdasarkan rancangan SMS Petersen et al. (2009) seperti pada Gambar 3.

\section{HASIL DAN PEMBAHASAN}

Berdasarkan proses SMS pada Gambar 3, berikut adalah penjelasan setiap tahap SMS yang dilakukan dalam artikel ini: Pertama, menentukan pertanyaan penelitian atau tahap definition of research question. Pada tahap ini Penulis melakukan hal-hal sebagai berikut: (a) memilih tema. Berdasarkan latar belakang di atas, tema yang dipilih adalah pendidikan kewirausahaan (PK), pengajaran kewirausahaan (AK), dan pembelajaran kewirausahaan (BK). Tema ini diangkat berdasarkan hasil pengamatan Penulis terhadap proses acara dan tanya jawab peserta dengan panelis selama berlangsung acara REE serta wawancara penulis dengan sembilan informan pendidik bidang studi kewirausahaan yang menjadi peserta REE. Informan terdiri dari dua dosen kewirausahaan dari sekolah tinggi keperawatan dan kebidanan, dua orang fasilitator pelatihan kewirausahaan dari lembaga swadaya masyarakat (LSM), satu orang pelaksana corporate social responsibility (CSR) perusahaan BUMN, satu orang pelaksana corporate social responsibility (CSR) perusahaan swasta, satu dosen kewirausahaan sekolah tinggi pariwisata, satu orang dosen kewirausahaan dari fakultas ilmu sosial dan ilmu politik, serta satu orang dosen kewirausahaan dari D3 Perpajakan.

Pertanyaan awal yang diberikan pada setiap informan adalah "apa tanggapan bapak/ ibu terhadap pendidikan kewirausahaan yang selama ini sudah bapak/ibu praktikkan?". Hasil pengamatan dan wawancara Penulis ringkas seperti yang dijelaskan dalam latar belakang di atas, (b) menentukan kajian tematis. Target tahap ini adalah menemukan tema yang merangsang wawasan kedepan dan cocok dengan kebutuhan PK. Berdasarkan latar belakang di atas, Penulis menentukan kajian tematis SMS dalam paper ini adalah 'Pendidikan, Pembelajaran, dan Pengajaran Kewirausahaan'. Secara empiris Bchini (2012)

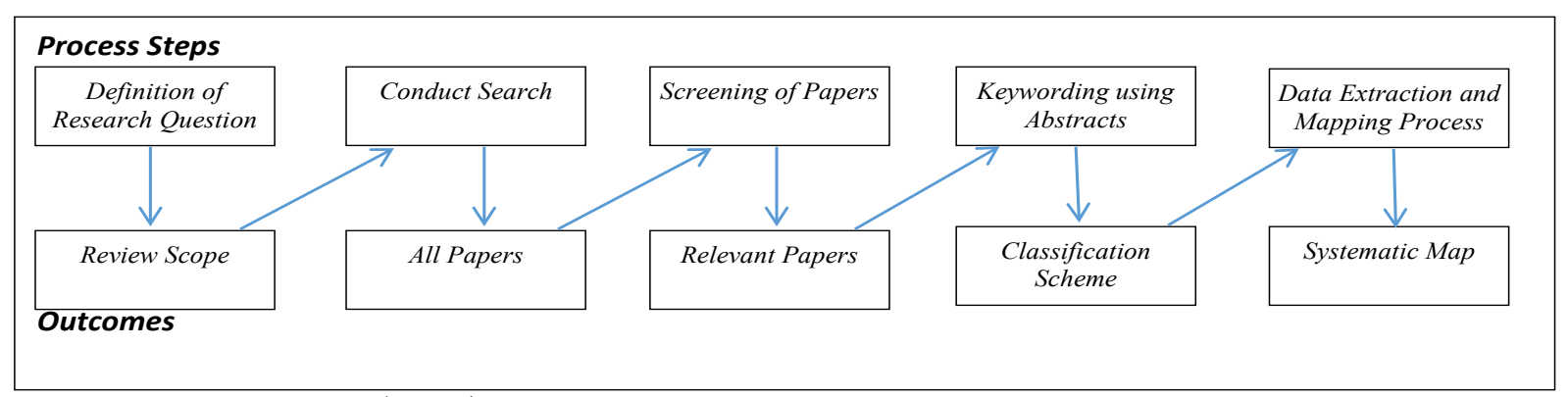

Sumber: Petersen et al. (2009)

Gambar 3. Proses Systematic Maps 
Margo Purnomo / Dinamika Pendidikan Kewirausahaan: Pemetaan Sistematis Terhadap...

menemukan bahwa penelitian terhadap pengajaran kewirausahaan cenderung kurang memperoleh perhatian para peneliti. Sementara Albornoz (2013) dan Purnomo (2014) menemukan bahwa sulit sekali mengidentifikasi strategi pembelajaran dan pengajaran yang tepat dalam kewirausahaan karena variasinya yang sangat banyak dan (c) membuat pertanyaan penelitian yaitu:

Pertanyaan penelitian 1: Area apa saja yang ada dalam PK?

Pertanyaan penelitian 2: Area apa saja yang ada dalam AK?

Pertanyaan penelitian 3: Area apa saja yang ada dalam BK?

Pertanyaan penelitian 4: Berapa banyak artikel yang tercakup dalam setiap area?

Pencarian pustaka atau tahap conduct research. Pencarian literatur yang relevan dilakukan dengan memanfaatkan web based search engines, yaitu Google. Memanfaatkan Google dalam SLR pada penelitian kewirausahaan sebelumnya dilakukan juga oleh Brown (2007); Gursel (2013); Idrees et al. (2013); dan Purnomo (2014). Gray et al. (2012); Gehanno et al. (2013); dan Giustini \& Boulos (2014) berpendapat bahwa para peneliti SLR dapat mengandalkan mesin pencari
Google karena Google bermanfaat untuk penelitian khususnya initial research. Pencarian dengan web based search engines dilakukan pada tanggal 28 Juni 2014 dengan keywords: entrepreneurship education, entrepreneurship teaching dan entrepreneurship learning. Pencarian dengan keywords entrepreneurship education menampilkan 418 pustaka paling relevan dengan keywords, ditampilkan dari 0 ke 1 sampai 0 ke 42 atau halaman layar ke 1 sampai 42. Pencarian dengan keywords entrepreneurship teaching menampilkan 459 pustaka paling relevan dengan keywords, ditampilkan dari 0 ke 1 sampai 0 ke 46 atau halaman layar ke 1 sampai 46. Sedangkan dengan keywords entrepreneurship learning menampilkan 528 pustaka paling relevan, ditampilkan dari 0 ke 1 sampai 0 ke 53 atau halaman layar ke 1 sampai 53.

Pemilahan tahap screening of papers dipilah pustaka yang relevan dan cocok dengan kajian tematis yang telah diputuskan. Pada tahap pemilahan Penulis juga mengacu Idrees et al. (2013) dan hasilnya ditampilkan dalam Tabel 2.

Tabel 3 adalah deskripsi umum literatur yang cocok menjadi referensi. Total sebanyak 111 artikel yang mengkaji $\mathrm{PK}, \mathrm{BK}$, dan AK.Tren jumlah artikel cenderung meningkat sejak tahun 2003. Hal ini menunjukkan bahwa penelitian dan kajian terhadap pendidikan,

Tabel 2. Tahap Pemilahan Literatur

\begin{tabular}{llll}
\hline & Langkah 1 & Langkah 2 & Langkah 3 \\
\hline Deskripsi & $\begin{array}{l}\text { Literatur } \\
\text { relevan }\end{array}$ & $\begin{array}{l}\text { Pemilahan literatur } \\
\text { karya ilmiah } \\
\text { yang relevan }\end{array}$ & $\begin{array}{l}\text { Pemilihan literatur } \\
\text { karya ilmiah yang } \\
\text { cocok dengan } \\
\text { kajian tematis }\end{array}$ \\
\hline $\begin{array}{l}\text { Jumlah temuan dengan keywords: } \\
\text { "entrepreneurship education" }\end{array}$ & 418 & 143 & 38 \\
\hline $\begin{array}{l}\text { Jumlah temuan dengan keywords: } \\
\text { "entrepreneurship teaching" }\end{array}$ & 459 & 102 & 53 \\
\hline $\begin{array}{l}\text { Jumlah temuan dengan keywords: } \\
\text { "entrepreneurship learning" }\end{array}$ & 528 & 98 & 20 \\
\hline Jumlah & & & 111 \\
\hline
\end{tabular}

Sumber: Tabel di adaptasi dari Idreeset al. (2013) 
Tabel 3. Gambaran Umum Literatur Pengajaran dan Pembelajaran Kewirausahaan

\begin{tabular}{|c|c|c|c|c|}
\hline No & Kategori & Sub-Kategori & Jumlah & Persentase \\
\hline \multirow[t]{6}{*}{1} & \multirow[t]{6}{*}{ Sumber Literatur } & Jurnal & 52 & 46,85 \\
\hline & & Makalah/Prosiding Seminar & 40 & 36,04 \\
\hline & & Laporan Lembaga Pemerintah/Swasta & 15 & 13,51 \\
\hline & & Tesis & 1 & 0,90 \\
\hline & & Disertasi & 3 & 2,70 \\
\hline & & Jumlah & 111 & 100 \\
\hline \multirow[t]{5}{*}{2} & \multirow[t]{5}{*}{ Tahun } & Sebelum 2003 & 4 & 3,60 \\
\hline & & $2003-2006$ & 17 & 15,32 \\
\hline & & $2007-2010$ & 36 & 32,43 \\
\hline & & $2011-2014$ & 54 & 48,65 \\
\hline & & Jumlah & 111 & 100 \\
\hline \multirow[t]{7}{*}{3} & \multirow{7}{*}{$\begin{array}{l}\text { Asal Peneliti/ } \\
\text { Penulis }\end{array}$} & Asia & 27 & 24,32 \\
\hline & & Amerika & 34 & 30,63 \\
\hline & & Afrika & 13 & 11,71 \\
\hline & & Eropa & 32 & 28,83 \\
\hline & & Australia & 3 & 2,70 \\
\hline & & Tidak Dicantumkan & 2 & 1,80 \\
\hline & & Jumlah & 111 & 100 \\
\hline
\end{tabular}

Sumber: data yang diolah (2014)

pengajaran dan pembelajaran kewirausahaan cenderung semakin memperoleh perhatian para peneliti.Jika dihubungkan dengan adanya peningkatan tren perhatian terhadap pendidikan kewirausahaan dalam satu dekade terakhir (Pittaway et al., 2008; Purnomo, 2014) maka ini indikasi bahwa pendidikan, pengajaran dan pembelajaran kewirausahaan merupakan bidang penelitian baru yang sedang diperhatikan. Artikel di dominasi oleh penulis dari Amerika dan Eropa. Hal ini wajar karena secara umum diketahui bahwa Amerika dan Eropa dipandang sebagai penggagas PK (Kuratko, 2003).

Skema pengelompokan atau tahap keywording using abstract. Hasil pada tahap ini adalah skema pengelompokkan artikel. Keywording dilakukan dengan dua langkah. Langkah pertama Penulis meninjau abstrak serta memperhatikan kata kunci dan konsepkonsep dalam artikel yang mencerminkan kontribusi artikel terhadap $\mathrm{PK}, \mathrm{AK}$ dan BK. Penulis pada saat yang sama juga memperhatikan konteks artikel. Langkah kedua Penulis menggabungkan kata kunci dalam satu kategori yang sama. Ketika Penulis mengalami kesulitan mengkategorikan, Penulis memperdalam pemahaman artikel dengan cara melihat bagian pengantar, pendahuluan, atau kesimpulan artikel. Hasil pengelompokkan kata kunci menjadi sub fokus tema seperti disampaikan dalam Tabel 4.

Pemetaan atau tahap data extraction and mapping process. Setelah memiliki skema pengelompokkan selanjutnya artikel yang relevan digabung dalam kategori yang sama. Artikel yang cocok dikelompokkan berdasarkan persamaan tema. Hasil pengelompokkan disampaikan di Tabel 4. Berdasarkan skema pengelompokkan diketahui bahwa pada fokus tema PK ada 38 artikel dan terbagi ke dalam tiga kelompok sub fokus tema/area yaitu kebijakan dalam PK, PK dalam konteks business entrepreneurship, dan PK dalam konteks non-business entrepreneurship; fokus tema AK memiliki 53 artikel dan terbagi ke dalam tujuh kelompok sub fokus tema/area yaitu tujuan dan kebutuhan pengajaran, pendekatan pengajaran, penyusunan kurikulum, infrastruktur pengajaran, evaluasi pengajaran, teknik 
Margo Purnomo / Dinamika Pendidikan Kewirausahaan: Pemetaan Sistematis Terhadap...

Tabel 4. Pembagian Fokus Tema dan Sub Fokus Tema

\begin{tabular}{|c|c|c|c|c|}
\hline Fokus Tema & Sub Fokus Tema & Penulis/Peneliti & Jumlah & $\%$ \\
\hline \multirow[t]{3}{*}{$\begin{array}{l}\text { Pendidikan } \\
\text { Kewirausahaan }\end{array}$} & $\begin{array}{l}\text { Kebijakan } \\
\text { dalam PK }\end{array}$ & $\begin{array}{l}\text { Awasthi, 2012; Ogundele \& Abiola, 2006; Zhou \& Xu, 2012; } \\
\text { Fan et al., 2013; ACE Initiative Development Committee, } \\
\text { 2009; Cooney \& Murray, 2008; Pittaway \& Cope, 2006; } \\
\text { Ramanigopal et al., 2012; Aspen Youth Entrepreneurship } \\
\text { Strategy Group, 2008; Kaijage \& Wheeler, 2013; Dreisler, } \\
\text { 2007; Edelman et al., 2008; Lefebvre \& Collot, 2012; } \\
\text { Mäkimurto-Koivumaa, 2012; Dragusin \& Balalia, 2010; } \\
\text { Babwah, 2012; Williamson et al., 2013; Klerk \& Dippenaar, } \\
\text { 2003; Todorov \& Papazov, 2009; Streeter \& Jaquette, 2004; } \\
\text { Kailer, 2006; Kefalas et al., 2012; }\end{array}$ & 22 & \\
\hline & $\begin{array}{l}\text { PK dalam } \\
\text { Konteks } \\
\text { Business } \\
\text { Entrepreneurship }\end{array}$ & $\begin{array}{l}\text { Ras \& Pretorius, 2007; Fitriati, 2012; Soare, 2008; Larsen \& } \\
\text { Nagel, 2013; Weber et al, 2009; Charney \& Libecap, 2005; } \\
\text { NSCL, 2012; AYESG, 2008; }\end{array}$ & 8 & 7,21 \\
\hline & $\begin{array}{l}\text { PK dalam } \\
\text { Konteks } \\
\text { Non-Business } \\
\text { Entrepreneurship }\end{array}$ & $\begin{array}{l}\text { Calvert, 2011; Frazier et al, 2011; EACA, 2012; Cranwell et al, } \\
\text { 2005; Dodescu \& Badulescu, 2010; Marques \& Albuquerque, } \\
\text { 2012; Huber et al., 2012; GVEPI, 2010; }\end{array}$ & 8 & 7,21 \\
\hline \multirow[t]{7}{*}{$\begin{array}{l}\text { Pengajaran } \\
\text { Kewirausahaan }\end{array}$} & $\begin{array}{l}\text { Tujuan \& Kebu- } \\
\text { tuhan Pengajaran }\end{array}$ & $\begin{array}{l}\text { Linan, 2004; Hamidi et al, 2008; Muofhe \& Toit, 2011; Lorz, } \\
\text { 2012; Kalyani \& Kumar, 2011; Lindner, 2012; Albornoz, 2013; }\end{array}$ & 7 & 6,31 \\
\hline & $\begin{array}{l}\text { Pendekatan } \\
\text { Pengajaran }\end{array}$ & $\begin{array}{l}\text { Bechard \& Toulouse, 1995; Popta, 2002; Otuya et al., 2013; } \\
\text { Wee, 2004; Priyanto, 2012; Painter, 2007; Honig, 2004; } \\
\text { Rasmussen \& Sørheim, 2006; Mansor \& Othman, 2011; White } \\
\text { et al, 2011; Hindle, 2007; Dreisler, 2007; Kleemann, 2011; } \\
\text { Naderi et al., 2013; Lackéus et al., 2013;; Shaikh et al., 2014; } \\
\text { Thornberry, 2002; Hanke et al., 2005; Venesaar \& Kolbre, } \\
\text { 2007;Stylman \& Hannula, 2007. }\end{array}$ & 20 & \\
\hline & $\begin{array}{l}\text { Penyusunan } \\
\text { Kurikulum }\end{array}$ & Onojetah \& Amiaya, 2013; AOC, 2013; & 2 & 1,80 \\
\hline & $\begin{array}{l}\text { Infrasruktur } \\
\text { Pengajaran }\end{array}$ & $\begin{array}{l}\text { Hindle, 2002; Gelderen \& Verduyn, 2003; Allegra et al., 2013; } \\
\text { Nasrudin \& Othman, 2012; Koopman et al., 2014; Klapper, } \\
\text { 2010; BGI, 2011; Tasnim \& Yahya, } 2013 .\end{array}$ & 8 & 7,21 \\
\hline & $\begin{array}{l}\text { Evaluasi } \\
\text { Pengajaran }\end{array}$ & $\begin{array}{l}\text { Antonciq et al., 2007; von Graevenitz et al., 2010; Bchini, 2012; } \\
\text { Borcher \& Park, 2011; Leino et al., 2009; Frazao et al., 2007; } \\
\text { Andrijevskaja, 2007; Monteros \& van Dorp, } 2009\end{array}$ & 8 & 7,21 \\
\hline & Teknik mengajar & $\begin{array}{l}\text { Egge, 2006; Venesaar \& Kolbre, 2007; Kralj, 2005; Pihie \& } \\
\text { Sani, 2009; Ying, 2007; Lonappan, 2013; Neck \& Greene, } \\
\text { 2011. }\end{array}$ & 7 & 6,31 \\
\hline & $\begin{array}{l}\text { Keterampilan } \\
\text { spesifik }\end{array}$ & Rosiński \& Klich, 2007 & 1 & 0,90 \\
\hline \multirow[t]{3}{*}{$\begin{array}{l}\text { Pembelajaran } \\
\text { Kewirausahaan }\end{array}$} & $\begin{array}{l}\text { Kualifikasi } \\
\text { pembelajaran }\end{array}$ & EAR, 2006 & 1 & 0,90 \\
\hline & $\begin{array}{l}\text { Pembelajaran } \\
\text { Tradisional }\end{array}$ & $\begin{array}{l}\text { Mauchil et al., 2011; Arasti et al., 2012; Holtsch\& Hoppe, } \\
\text { 2007; White et al., 2011. }\end{array}$ & 4 & 3,60 \\
\hline & $\begin{array}{l}\text { Pembelajaran } \\
\text { Inovatif }\end{array}$ & $\begin{array}{l}\text { Tervonen, 2007; Dalin, 2008; Ehiobuche et al., 2012; } \\
\text { Frederick, 2007; Jarna et al., 2006; Heriot et al., 2012; Hickey } \\
\text { \& Salas, 2013; Stylman \& Hannula, 2007; Malinen \& Partanen, } \\
\text { 2007; Kirketerp, 2011; Mansor \& Othman, 2011; Rodríguez et } \\
\text { al., 2012; Romo et al., 2013; Sidhu et al., 2014; Suonpaa, } 2013\end{array}$ & 15 & \\
\hline
\end{tabular}

Sumber: data yang diolah (2014)

Jumlah $111 \quad 100$


mengajar, dan keterampilan spesifik; dan fokus tema BK memiliki 20 artikel dan terbagi ke dalam tiga sub fokus tema/area yaitu kualifikasi pembelajaran, pembelajaran tradisional, dan pembelajaran inovatif.

\section{Pendidikan Kewirausahaan}

PKtidak menjanjikan dapat menghasilkan wirausaha sukses, namun kebijakan terhadap PK dapat memicu peningkatan pengetahuan dan keterampilan yang diperlukan untuk berperilaku entrepreneurial (Klerk \& Dippenaar, 2003). Evaluasi terhadap PK dapat dilakukan dengan cara melihat hasil ujian tingkat pengetahuan dan keterampilan berwirausaha peserta belajar, mengevaluasi pelajaran dan pengajar kewirausahaan, serta mengevaluasi indikator-indikator demografis seperti tingkat pendapatan, angka pengangguran, ketersediaan lapangan kerja, dan pertumbuhan jumlah perusahaan (Nasrudin \& Othman, 2012).

Guna mendukung peningkatan pada aspek-aspek tersebut maka kebijakan PK dapat dikelompokkan dalam tiga ranah kebijakan, yaitu tingkat makro, meso, dan mikro (Audretsch et al., 2006 \& Karlsson et al., 2006). Pada ranah makro, kebijakan PK bersifat strategis dan berada pada tingkat negara. Kebijakan di tingkat ini diperlukan sebagai payung bagi institusi-institusi penyelenggara PK, berkenaan dengan kerangka kebijakan yang dapat dilakukan pemerintah dan stakeholder untuk membangun kondisi yang mendukung terhadap efektivitas dan efisiensi PK di suatu negara atau wilayah. Pada ranah ini diketahui bahwa tidak efektifnya PK disebabkan oleh kurangnya evaluasi terhadap PK, rendahnya dukungan politik dan infrastruktur, serta $\mathrm{PK}$ diposisikan sebagai "isolated island". Oleh sebab itu, para ahli membuat rekomendasirekomendasi kebijakan makro PK seperti disampaikan dalam Tabel 5.

Kebijakan PK pada ranah mezzo berkenaan dengan kebijakan yang dapat dilakukan oleh institusi penyelenggara PK dalam mengimplementasikan kebijakan di ranah makro, khususnya berkenaan dengan pengelolaan dan rancangan pendidikan kewirausahaan di lembaga-lembaga pendidikan.

Tabel 5. Rekomendasi Kebijakan Makro Pendidikan Kewirausahaan

\begin{tabular}{ll}
\hline No & \multicolumn{1}{c}{ Rekomendasi Kebijakan Makro Pendidikan Kewirausahaan } \\
\hline 1 & Sistem pendidikan kewirausahaan dirancang sejak pendidikan dasar sampai universitas \\
2 & Memberikan dukungan untuk pengadaaan infrastruktur pendidikan yang memadai \\
3 & Membangun kolaborasi antara sekolah/universitas, institusi bisnis, masyarakat, dan pemerintah \\
4 & Meningkatkan penelitian, evaluasi, dan perbaikan yang berkelanjutan \\
5 & Mengurangi hambatan latar belakang budaya, pendidikan, gender, dan usia dalam berwirausaha \\
6 & Mempromosikan kewirausahaan sebagai pilihan karir \\
7 & Pendidikan khusus untuk pengajar kewirausahaan \\
8 & Membangun lingkungan sosial, politik, dan budaya yang mendukung perilaku berwirausaha \\
9 & Meningkatkan technology literacy dalam berwirausaha \\
10 & Membangun Fakultas Kewirausahaan \\
11 & Mencocokan antara praktik berwirausaha dengan materi kewirausahaan pada buku textbook \\
12 & Membangun legitimasi politis \\
13 & Restorasi moral wirausahawan \\
14 & Meningkatkan peran wanita, pemuda, dan daerah rural \\
15 & Pendidikan, pengajaran, dan pembelajaran kewirausahaan multi disiplin \\
\hline
\end{tabular}

Sumber: data yang diolah (2014) 
Margo Purnomo / Dinamika Pendidikan Kewirausahaan: Pemetaan Sistematis Terhadap...

Contoh kebijakan pada ranah mezo yang diantaranya adalah Objectives-CurriculumEvaluation (Babwah, 2012; Kailer, 2006), program kolaborasi sekolah/universitasperusahaan-masyarakat/ market (Dragusin \& Balalia, 2010; Klerk \& Dippenaar, 2003; Williamson et al., 2013; Todorov \& Papazov, 2009); Magnet Vs Radiant Program (Streeter \& Jaquette, 2004), dan Flying-Faculty Model (Kefalas et al., 2012).

Secara umum diketahui bahwa para penyelenggara PK berkiblat ke Amerika dan Eropa (Kuratko, 2003). Di Amerika umumnya kewirausahaan dipandang sebagai growth-oriented ventures. Karena itu, PK di Amerika lebih menekankan pada keterampilan membangun, membiayai, dan mempercepat pertumbuhan perusahaan. Sedangkan di Eropa, kewirausahaan berkenaan dengan usaha kecil dan menengah (UKM) serta pengembangan entrepreneurial capacity untuk mendukung aktivitas sehari-hari di rumah, di dunia kerja, dan di masyarakat baik dalam akivitas sosial maupun aktivitas komersial. Australia lebih banyak dipengaruhi oleh Eropa. Sementara Asia dan Afrika, walaupun dipengaruhi Amerika dan Eropa namun kewirausahaan umumnya dipandang sebagai menciptakan atau membangun perusahaan.

Terakhir, kebijakan pada ranah mikro adalah kebijakan teknis di dalam kelas yang dirancang oleh pendidik/guru/dosen/ fasilitator kewirausahaan agar pembelajaran dan pengajaran kewirausahaan efektif dan efisien. Hal-hal yang berkenaan dengan kebijakan mikro akan dibahas pada fokus tema pengajaran dan pembelajaran kewirausahaan.Kesenjangan empiris yang ditemukan dalam kategori kebijakan dalam PK diantaranya adalah kajian kebijakan PK pada umumnya berupaya untuk menjelaskan kebijakan PK pada ranah makro dan mikro.

Tahap skema pengelompokkan dengan menggunakan kata kunci menunjukkan bahwa PK bukan monopoli lembaga pendidikan binis. Hal membuktikan bahwa kewirausahaan semakin berkembang dan kontekstual. Karena itu pengelompokkan dibagi menjadi dua sub fokus tema yaitu PK dalam konteks business entrepreneurship dan PK dalam konteks nonbusiness entrepreneurship. Pada sub fokus tema kedua, ditemukan ada enam konteks PK, yaitu social entrepreneurship education (Calvert, 2011), urban/rural entrepreneurship education (Frazier et al., 2011), food entrepreneurship education (Cranwell et al., 2005), woman entrepreneurship education (Dodescu \& Badulescu, 2010), early \& youth entrepreneurship education (Marquez \& Albuquerque, 2012; Huber et al., 2012; EACA, 2012), energy entrepreneurship education (GVEPI, 2010), dan engineering entrepreneurship education (MäkimurtoKoivumaa, 2012). Temuan ini mengindikasikan bahwa PK semakin berkembang dan spesifik, menyesuaikan diri dengan kebutuhan di masyarakat. Sebagai contoh, ahli dari Irlandia bernama Thomas Cooney dan Trudie Murray memperkenalkan diri dari lembaga PK yang khusus memperhatikan minority entrepreneurship. Perkembangan ini memberikan arahan kedepan bahwa area bidang penelitian PK semakin meluas dan spesifik. Walaupun demikian saat ini penelitian PK dalam konteks business entrepreneurship masih mendominasi.

\section{Pengajaran Kewirausahaan}

Pada fokus tema ini Penulis menemukan adanya inkonsistensi dalam menentukan tujuan AK sebagaimana ditemukan juga oleh Bechard dan Toulouse (1995), Albornoz dan Rocco (2009), dan Albornoz (2012). Walau begitu secara umum Penulis mengidentifikasi ada lima tujuan AK di perguruan tinggi yang umum dikemukakan dalam artikel kelompok ini, yaitu a) membangun kesadaran berwirausaha; b) penciptaan usaha baru; c) pengembangan usaha mikro, kecil dan menengah; d) intrapreneurship; e) pengembangan pendidik kewirausahaan; dan f) membangun masyarakat yang bebas dan bertanggung jawab. Selain tujuan, sub fokus selanjutnya yang muncul adalah kebutuhan pengajaran.Di sini aspek yang perlu diperhatikan 
diantaranya adalah penilaian tingkat kreativitas peserta (Hamidi et al., 2008), entrepreneurial intention dan role model peserta (Muofhe \& Toit, 2011; Lorz, 2012), serta faktor-faktor yang memotivasi peserta berwirausaha seperti ambisi, kebutuhan ekonomi, keinginan untuk mandiri, bantuan pemerintah, pengalaman, potensi pasar, potensi laba, dan kualifikas pribadi (Kalyani \& Kumar, 2011).

Guna memenuhi tujuan dan kebutuhan tersebut maka pada sub tema selanjutnya membahas tentang pendekatan pengajaran. Disini hampir semua penulis konsisten mengkritisi penggunaan desain pedagogis konvensional yang cenderung teacher centered. Kalaupun tetap menjalankan desain pedagogi konvensional Klapper (2010) merekomendasikan untuk menggunakan innovative pedagogy, atau pendapat Tasnim dan Yahya (2013) yaitu active pedagogy. Upaya yang baik dan menarik dilakukan oleh Lackeus et al. (2013) yang berusaha membuat kerangka kerja tentang dualisme pengajaran kewirausahaan. Onojetah dan Amiaya (2013) mengusulkan pendekatan baru pada kurikulum kewirausahaan, yaitu The Multiple Contexts of Entrepreneurship Education/Studies Curriculum and Instruction. Pendekatan ini berusaha mengikuti perkembangan kewirausahaan yang semakin kontekstual.

Sub tema selanjutnya adalah infrastruktur pengajaran. Pada sub tema ini, program kewirausahaan yang seimbang setidaknya mengandung empat komponen: (a) membangun budaya entrepreneurial; (b) dukungan kebijakan yang mengawal terhadap pengadaan sumber daya, riset pasar, ruangan, dana awal, paten, konseling dan pendampingan, serta teknologi; (c) dukungan stakeholder seperti pemerintah, masyarakat, industry, jaringan alumni, dan praktisi; dan yang terpenting adalah (d) pengajar yang kompeten dan siap. Berdasarkan sub fokus evaluasi pengajaran, diketahui ada dua alasan lemahnya dukungan infrastruktur AK. Pertama tidak ada kesepakatan substantif tentang apa itu kewirausahaan ketika diajarkan (Frazao et al.,
2007), dan Kedua, konten apa saja yang tepat sehingga layak untuk dibahas secara permanen (Leino et al., 2009).

Ketidaksepakatan tersebut wajar karena seperti yang dikatakan oleh Sarasvathy dan Venkataraman (2011) bahwa kewirusahaan merupakan fenomena yang sangat heterogen, atau pendapat Garavan dan Cinneide (1994) yang berkata bahwa sampai saat ini kita tidak tahu bagaimana wirausahawan belajar. Walaupun demikian, banyak penulis artikel yang "mengimani" bahwa cara menjanjikan untuk meningkatkan perilaku entrepreneurial dan minat berwirausaha adalah meningkatkan kualitas AK. Karena itu, evaluasi berkelanjutan efektvitas AK penting dilakukan.Ini dapat dilakukan dengan mengevaluasi kepuasan peserta (Antonciq et al., 2007), model mental peserta (Borcher \& Park, 2011), student's self-assessed entrepreneurial skill (von Graevenitz et al., 2010), dan teacher selfreflection (Leino et al., 2009).

Pada sub fokus infrastruktur pengajaran, muncul juga tema tentang media pengajaran. Media pengajaran berperan menjembatani transfer pengetahuan dan keterampilan. Media pengajaran inovatif yang disarankan diantaranya adalah film (Gelderen \& Verduyn, 2003) dan serious game simulation (Allegra et al., 2013). Kelebihan film adalah dapat mentransfer emosi, dilema moral, dan hubungan interpersonal sehingga efektif memotivasi peserta.

Media kedua yaitu serious game simulation. Media inimemberikan pengalaman pada peserta berupa learning by doing serta learning by failing dalam situasi yang komplek dan kompetitif. Sub fokus selanjutnya adalah teknik mengajar. Pada sub fokus tersebut diketahui bahwa pengalaman nyata berwirausaha sangat diapresiasi oleh peserta belajar. Karena itu teknik mengajar seperti mengundang pengajar dari praktisi (Egge, 2006), studi kasus (Kralj, 2005) dan wawancara dengan wirausahawan (Pihie \& Sani, 2009) dipandang efektif. Pemetaan teknik AK dilakukan oleh Neck dan Greene (2011) dan membuat ringkasan tentang teknik AK dimana pengajar biasanya melibatkan salah satu atau beberapa teknik berikut: Pertama, the 
Margo Purnomo / Dinamika Pendidikan Kewirausahaan: Pemetaan Sistematis Terhadap...

Tabel 4. Model-Model Pembelajaran Inovatif

\begin{tabular}{lll}
\hline No & Model Pembelajaran Inovatif & Penulis \\
\hline 1 & Virtual-Based Business Plan & Tervonen, 2007 \\
2 & Open Teaching Model & Dalin, 2008; \\
3 & Dialogue Model & Ehiobuche, 2012 \\
4 & Blended Learning & Frederick, 2007 \\
5 & Entrepreneurial-directed & Jarna et al, 2006 \\
6 & Adjunct Faculty & Heriot et al, 2012 \\
7 & Entrepreneur's Bootcamp & Hickey \& Salas, 2013 \\
8 & Competence-based entrepreneurship & Stylman \& Hannula, 2007; \\
9 & Entrepreneurship Path Cooperation & Malinen \& Partanen, 2007; \\
10 & The Push Method & Kirketerp, 2011 \\
11 & Consulting-based Learning & Mansor \& Othman, 2011 \\
12 & Multidisciplinary Teams & Rodríguez et al., 2012 \\
13 & Entrepreneurship Based Learning & Romo et al., 2013 \\
14 & Berkeley Method of Entrepreneurship & Sidhu et al., 2014 \\
15 & Opportunity Centred Collaborative Learning & Suonpaa, 2013 \\
\hline
\end{tabular}

Sumber: data yang diolah (2014)

Entrepreneur World. Model ini menitikberatkan pada kepribadian wirausahawan sebagai super hero. Peserta diajak untuk mengidentifikasi profil karakter wirausahawan sukses. Pengajar lalu mendeskripsikan tentang kepribadian wirausahawan seperti pengendalian diri, toleransi terhadap ketidakpastian, kecenderungan untuk mengambil resiko, dan hasrat untuk berprestasi.

Kedua, the Process World. Model ini menitikberatkan pada penciptaan perusahaan baru. Peserta diajak membuat perencanaan dan memprediksi ide entrepreneurial yang dimiliki. Pengajar memberikan arahan tentang pembuatan rencana bisnis, analisis kasus, dan model bisnis. Ketiga, the Cognition World. Model ini menitikberatkan pada bagaimana mengidentifikasi peluang dan mengelola pengetahuan sebagai sumber daya berwirausaha. Pengajar memberikan metodemetode pangambilan keputusan dalam aktivitas entrepreneurial.

Keempat, the Method World. Model ini menitikberatkan pada praktik berwirausaha. Praktik disesuaikan dengan konteks kewirausahaan yang akan didalami. Pengajar bertugas mengajak peserta merefleksikan praktik dan eksperimen yang telah dilakukan. Sub fokus terakhir adalah pengajaran keterampilan spesifik untuk berwirausaha, pada sub fokus ini Rosiński dan ntingnya mengajarkan keterampilan bernegosiasi bagi para perserta belajar kewirausahaan.

\section{Pembelajaran Kewirausahaan}

Fokus tema ini berkaitan dengan proses belajar kewirausahaan. BK umumnya disederhanakan sebagai belajar bagaimana mengenali kesempatan atau peluang (Rae, 2003; Lumpkin \& Lichtenstein, 2005). Pada sub tema ini umumnya para ahli mengkritisi pembelajaran tradisional yang bersifat satu arah, atau top-down instructive (Lourenco \& Jones, 2006). Para penulis BK merekomendasikan agar peserta didik di ajak ke lapangan dan merasakan berwirausaha. Selain itu, hampir semua penulis mengkritisi penggunaan desain pedagogis yang pasive learning. Kalaupun tetap menjalankan desain pedagogi Klapper (2010) 

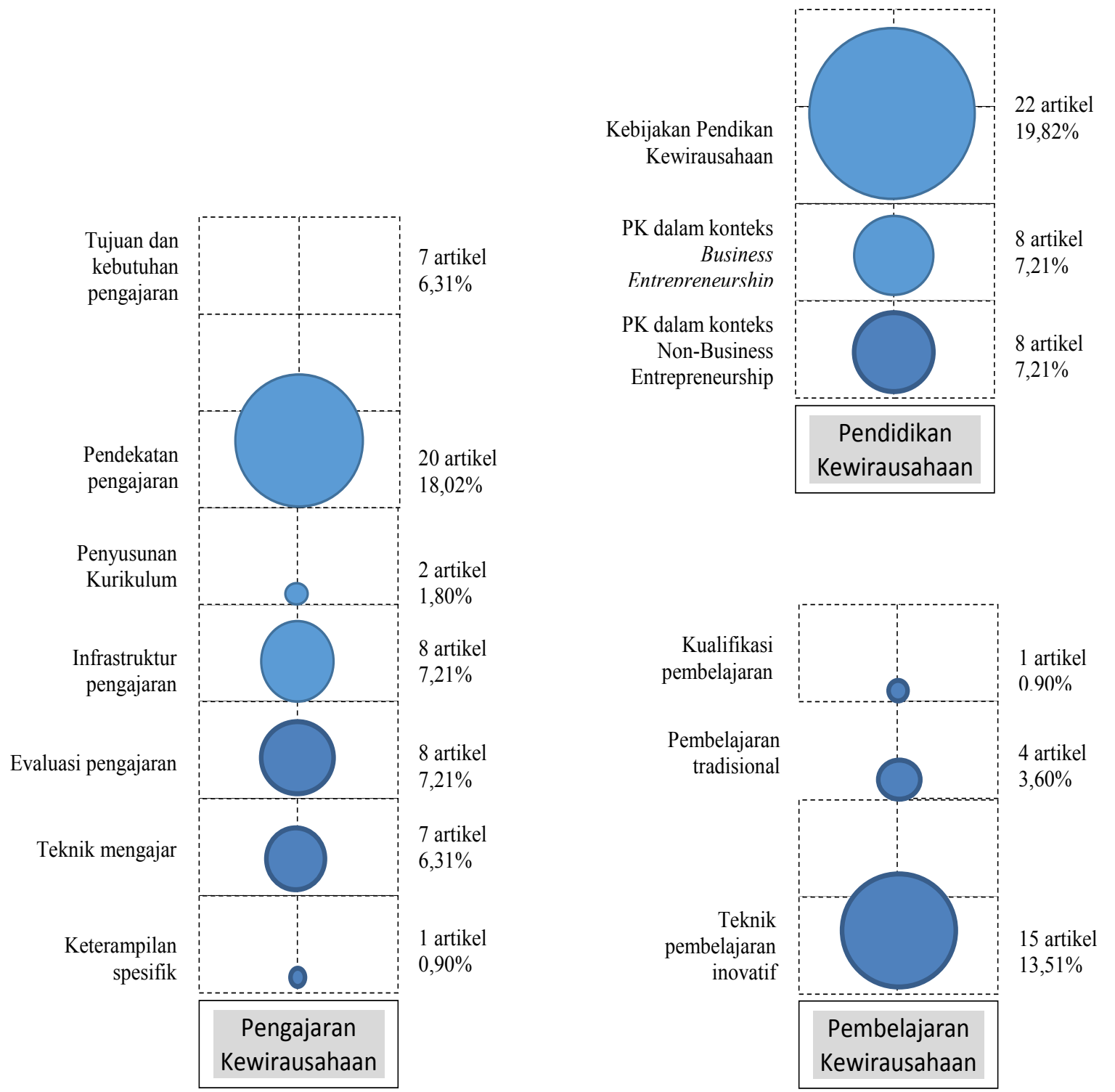

Sumber: data yang diolah (2014)

Gambar 3. Visualisasi Hasil Pemetaan Pendidikan Kewirausahaan

merekomendasikan untuk menggunakan innovative pedagogy, atau saran Tasnim \& Yahya (2013) yaitu active pedagogy. Karena itu pendekatan yang disarankan para penulis diantaranya adalah: experiential learning (Otuya et al., 2013), non-formal setting (Priyanto, 2012), problem-based learning (Wee, 2004), strategicbusiness plan (Painter, 2007; White et al., 2011; Arasti et al., 2012), action-based (Rasmussen \& Sorheim, 2006; Neck \& Greene, 2011), contingency-based business planning (Honig, 2004), dan consulting-based (Manshor \& Othman, 2011).
Pendekatan tersebut memposisikan peserta sebagai subjek dan pengajar sebagai fasilitator, bersifat bottom-up constructive. Tabel 6 adalah model pembelajaran inovatif yang diusulkan.Bagaimana pun juga usulan di atas umumnya masih merupakan draft. Karena sangat heterogen maka Penulis memandang ada langkah baik yang dilakukan oleh European Agency for Reconstruction (2006) di Denmark, yaitu merancang standar kualifikasi BK. Rancangan ini merupakan terobosan untuk menyikapi adanya lacking in coherent structure dalam bidang PK. 
Margo Purnomo / Dinamika Pendidikan Kewirausahaan: Pemetaan Sistematis Terhadap...

\section{Visualisasi Pemetaan}

Tabel 5 menunjukkan hasil ekstraksi dan pemetaan berupa frekuensi dan persentase dari setiap area PK berdasarkan skema pengelompokkan artikel. Selanjutnya berdasarkan hasil ekstraksi dan pemetaan Penulis membuat visualisasi seperti di tampilkan dalam Gambar 3.

\section{SIMPULAN DAN SARAN}

Perkembangan PK semakin kontekstual seiring dengan meluasnya konsep kewirausahaan. Berdasarkan hasil skema pengelompokkan artikel dalam proses SMS diketahui bahwa pada fokus tema PK ada 38 artikel dan terbagi ke dalam tiga kelompok sub fokus tema atau area yaitu kebijakan dalam PK, PK dalam konteks business entrepreneurship, dan PK dalam konteks non-business entrepreneurship; fokus tema $\mathrm{AK}$ memiliki 53 artikel yang relevan dan terbagi ke dalam tujuh kelompok sub fokus tema atau area yaitu tujuan dan kebutuhan pengajaran, pendekatan pengajaran, penyusunan kurikulum, infrastruktur pengajaran, evaluasi pengajaran, teknik mengajar, dan keterampilan spesifik; dan fokus tema BK memiliki 20 artikel dan terbagi ke dalam tiga sub fokus tema atau area yaitu kualifikasi pembelajaran, pembelajaran tradisional, dan pembelajaran inovatif.

Temuan ini sesuai dengan penyataan proposisi, yaitu pelaksanaan PK membutuhkan dukungan kebijakan dari pemerintah, lembaga pengelola, dan pelaksana PK di kelas-kelas kewirausahaan; PK memiliki bentuk yang heterogen tergantung konteks pelaksanaan PK; Pelaksanaan AK dilakukan secara kontekstual dan pengajar berperan memfasilitasi; dan Pelaksanaan BK dilakukan dengan pendekatanpendekatan inovatif. Artikel ini dapat memberikan wawasan baru untuk dilakukan penelitian lebih lanjut baik dengan SLR ataupun penelitian empiris khususnya pada bidang PK kontekstual.
Pendekatan terbaik dalam AK dan BK sampai dengan saat ini belum ada kesepakatan diantara para ahli. Walau demikian hasil SMS merekomendasikan bahwa pendekatan $\mathrm{AK}$ dan BK yang baik akan tergantung pada tujuan dan konteks PK. Tantangan meningkatkan kualitas PK bukan sekedar mengembangkan metode pengajaran yang berkualitas. Tetapi seperti yang disarankan Levebre \& Collot (2012) bahwa PK akan efektif jika didukung oleh legitimasi politik. Dukungan kebijakan yang terintegrasi baik pada ranah makro, meso, dan mikro sangat penting agar posisi PK tidak terisolasi serta pelaksanaan pembelajaran dan pengajaran yang inovatif, efektif, dan efisien dapat diselenggarakan. PK juga bukan sekedar transfer pengetahuan dan membangun keterampilan berbisnis namun merupakan pendidikan keterampilan hidup untuk jadi berdaya sekaligus investasi bagi negara.

\section{DAFTAR PUSTAKA}

ACE Initiative Development Committee. 2009. Entrepreneurship Education in Ireland: Towards Creating the Entrepreneurial Graduate, National Council for Graduate Entrepreneurship, Ireland.

Aja-Okorie, U \& Adali, O. 2013. Achieving Youth Empowerment Through Repositioning Entrepreneurial Education In Nigerian Universities: Problems \& Prospects. European Scientific Journal. 9 (2): 113-132.

Albornoz, C \& Rocco, T. S. 2009. Revisiting entrepreneurship education literature: Implications for learning \& teaching entrepreneurship. Proceedings. The Eighth Annual College of Education \& GSN Research Conference. Miami: Florida International University.

Albornoz, C. 2013. Revisiting entrepreneurship education literature: Implications for learning \& teaching entrepreneurship. Available at: http://digitalcommons. fiu.edu ${ }^{1} / \mathrm{cgi} /$ viewcontent.cgi? article $=1141 \&$ context $=$ sferc. Diunduh pada 29 Juni 2014.

Allegra, M., Guardia, D. L., Ottaviano, S., Grande, V. D \& Gentile, M. 2013. A serious game to promote \& facilitate entrepreneurship 
education for young students. Proceedings. The 2013 International Conference on Education \& Educational Technologies.

Andrijevskaja, J. 2007. Master Program in Entrepreneurship and Technology Management: Evaluation of the Successful Initiative in Estonia. Entrepreneurship Teaching \& Promotion at \& by Universities. University of Tartu (Estonia). Available at: http://interreg4c.eu/uploads/media/ pdf/2_Entrepreneurship_Teaching _ Promotion_at and_by_Universities_ BEPAR.pdf. Diunduh pada 29 Juni 2014.

Antoncic, B., Erzetic, B. H., Zorn, O \& Hisrich, R. D. 2007. Entrepreneurship Education: NonLinearity in the Satisfaction-Continuation Relationship.Management. 2 (2): 101-119.

Arasti, Z., Falavarjani, M .K. \& Imanipour, N. 2012. A Study of Teaching Methods in Entrepreneurship Education for Graduate Students.Higher Education Studies. 2 (1): 2-10.

Asadi, A \& Kohan, M. F. Z. 2011. The role of Entrepreneurship on Ecotourism development. Proceedings. International Conference on Sociality and Economics Development, IPEDR vol.10. IACSIT Press, Singapore.

Aspen Youth Entrepreneurship Strategy Group. 2008. Youth Entrepreneurship Education In America: A Policymaker's Action Guide. The Aspen Institute. One Dupont Circle, NW. Washington, DC.

Audretsch,D. B., Thurik, R., Verheul, I \& Wennekers, S. 2006. Entrepreneurship: Determinant and Policy in a European-US Comparison. Springer Science and Business Media.

Awasthi, D. 2011. Approaches to Entrepreneurship Development: The Indian Experience. Journal of Global Entrepreneurship Research. Winter \& Spring. 1 (1): 107-124.

Babwah, N.R. 2012. An Entrepreneurship Education Model For Trinidad \& Tobago. Journal of Emerging Trends in Educational Research \& Policy Studies. 3 (3): 307-311.

Bchini, B. 2012. Toward a Method for Evaluating the Teaching of Entrepreneurship. International Journal of Business and Social Science. 3 (15): 177-194.

Bechard, J. P \& Toulouse, J. M. 1995. Theoretical Foundations of Entrepreneurship Development Programs: an Exploratory Study. Proceedings. The Fifth Global Entrepreneurship Research Conference held in Salzburg (Austria), March 15-18.
Borcher, A \& Park, S. H. S. 2011. Assessing The Effectiveness of Entrepreneurial Education Programs From A Multi-Level MultiDimensionalperspective With Mental Models. American Society for Engineering Education.

Braunerhjelm, P. 2010. Entrepreneurship, Innovation \& Economic Growth: Past Experiences, Current Knowledge \& Policy Implications. Available at: http:// entreprenorskapsforum.se/wp-content/ uploads/2013/03/WP_02.pdf. Diunduh pada 3 Juli 2014.

Brock, D. D \& ASHOKA. 2008. Social Entrepreneurship: Teaching Resources Handbook. Ashoka's Global Academy for Social Entrepreneurship.

Brown, C. R. 2007. Economic Theories of The Entrepreneur: A Systematic Review Of The Literature. School of Management, Cranfield University. Available at: (https://dspace.lib. cranfield.ac.uk/ bitstream/1826/2152/1/ Chris\%20Brown\%20SR.pdf. Diunduh pada 9 Juli 2014.

Calvert, V. 2011. Service Learning to Social Entrepreneurship: A Continuum of Action Learning. Journal of Higher Education Theory and Practice. 11 (2): 118-129.

Charney, A \& Libecap, G. D. 2005. Impact of Entreprneurship Education, Insights, A Kauffman Research Series.

Cooney, T \& Murray, T. 2008. Entrepreneurship education in the third-level sector in Ireland. Institute for Minority Entrepreneurship \& The National Council for Graduate Entrepreneurship, United Kingdom.

Cranwell, M. R., Kolodinsky, J. M., Donnelly, C. W., Downing, D. L \& Zakour, O. I. P. 2005. A Model Food Entrepreneur Assistance \& Education Program: The Northeast Center for Food Entrepreneurship. Journal Of Food Science Education. 4 (1): 56-65.

Dalin, L. 2008. Open Teaching for Entrepreneurial Talent. China: School of Economics and Management Henan Polytechnie University.

Dodescu, A \& Badulescu, A. 2010. Entrepreneurship Education \& Training.Study-case. Proceedings. The AntrES programme on Women Entrepreneurship in Western Romania.

Dragusin, M. \& Balalia, A. E. 2010. Cooperation Between Smes And Higher Education Institutions-Effective Tool ForEntrepreneurial Education, Studia Universitatis Babeş-Bolyai. Negotia. 55 (1): 65-70. 
Margo Purnomo / Dinamika Pendidikan Kewirausahaan: Pemetaan Sistematis Terhadap...

Dreisler, P. 2007. Entrepreneurship-From Opportunity to Action-The Entrepreneurial Process.Entrepreneurship Teaching \& Promotion at \& by UniversitiesÅrhus School of Business-University of Århus (Denmark). Available at: http://interreg4c.eu/uploads/ media/pdf/2_Entrepreneurship_Teaching _ Promotion_at_and_by_Universities BEPAR.pdf. Diunduh pada 29 Juni 2014

Edelman, L. F., Manolova, T. S \& Brush, C. G. 2008. Entrepreneurship Education: CorrespondenceBetween Practices of Nascent Entrepreneurs \& Textbook Prescriptions for Success. Academy of Management Learning \& Education. 7 (1): 56-70.

Education, Audiovisual \& Culture Executive Agency. 2012. Entrepreneurship Education at School in Europe.National Strategies, Curricula and Learning Outcomes, Published by the Education, Audiovisual and Culture Executive Agency, Brussels. Available at: http://eacea.ec.europa.eu/ education/ eurydice. Diunduh pada 3 Juli 2014.

Egge, K. A. 2006. Former Students' Feedback On A Liberal Arts Undergraduate Course In Entrepreneurship. College Teaching Methods \& Styles Journal. 2 (2): 1-8.

Ehiobuche, C., Tu, H \& Justus, B. 2012. Dialogue As A Tool For Teaching \& Learning Of Entrepreneurship. Proceedings. ASBBS Annual Conference: Las Vegas. 19 (1).

European Agency for Reconstruction. 2006. Standards For Qualifications In Entrepreneurship Learning. Denmark: Aarhus Technical College.

Fan, Y., Zhang, X \& Qiu, Y. 2013. The State of Entrepreneurship Education in Universities in Shanghai, China: A Survey from Students' Perspective. Creative Education. 4 (2): 92-97.

Fayolle, A., Gailly, B. T \& Lassas-Clerc, N. 2006. Assessing the impact of entrepreneurship education programmes: a new methodology. Journal of European Industrial Training. 30 (8): 701-720.

Fitriati, R. 2013. Entrepreneurship Education: Towards Models in Several Indonesia's University, Proceedings. The $4^{\text {th }}$ International Conference on Indonesian Studies: Unity, Diversity, and Future.

Frazão, L., Santos, C., Oliveira, S \& Oliveira, T. 2007. Teaching entrepreneurship at Higher Education: the students' perception. The IPEC Project POCTICED/58825/2004, The Portuguese Foundation for Science \& Technology.
Frazier, B.J., Niehm, L.S \& Stoel, 1.2011. Connecting college learners with rural entrepreneurship opportunities: The rural entrepreneurship teaching unit, Journal of Case Studies in Education. Available at: http://www.aabri. com/manuscripts/111035. Diunduh pada 8 Juli 2014.

Frederick, H. H. 2007. Blended Learning in Entrepreneurship Education in the AsiaPacific: A Grounded Theory Approach to Entrepreneurship Pedagogy. Proceedings. Small Enterprise Conference 2007, 23-26 September.

Garavan, T \& O'Cinneide, B. 2014. Entrepreneurship Education\& Training Programmes: A Review \& EvaluationPart 1. Literature review of problems associated with entrepreneurship education \& training programmes, Journal of European Industrial Training. Available at: http://www. entrepreneur.dk/ entrprnship.htm. Diunduh pada 3 Juli 2014

Gehanno, J. F., Rollin, L \& Darmoni, S. 2013. Is the coverage of Google Scholar enough to be used alone for systematic reviews. Available at: http://www.ncbi.nlm.nih.gov/pmc/ articles/ PMC3733758/. Diunduh pada 9 Juli 2014.

Geldern, M \& Verduyn, K. 2003. Entrepreneurship in the cinema: Feature film as case material in entrepreneurship education. International Journal in Entrepreneurship Education. 1 (4)

Giustini, D \& Boulos, M. N. K. 2014. Google Scholar is not enough to be used alone for systematic reviews. Available at: http://www.ncbi.nlm. nih.gov/pmc/articles/ PMC3733758/. Diunduh pada 29 Juni 2014.

Global Village Energy Partnership International. 2010. Training Manual For Micro, Smalle Medium Entrepreneurs In Energy Business Financing. Developing Energy Enterprise Project, East Africa.

Gray, J. E., Hamilton, M. C \& Hauser, A. 2012. Scholarish: Google Scholar \& its value to the sciences. International Science Technology Librarianship. Available at: http://istl. org/12-summer/ article1.html. Diunduh pada 29 Juni 2014.

Gursel, D. 2013. Entrepreneurial Success Factor: A systematic approach to entrepreneur evaluation. Massachusetts Institute Of Technology. Available at: http://dspace.mit.edu/ bitstream/handle/ 1721.1/81075/857792889. pdf?sequence=1. Diunduh pada 9 Juli 2014 . 
Hamidi, D. Y., Wennberg, K \& Berglund, H. 2008. Creativity in Entrepreneurship Education, Journal of Small Business of Enterprise Development. 15 (2): 304-320.

Hanke, R. M., Kisenwether, E. C \& Warren, A. 2005. A Scalable and Adaptable ProblemBased Learning Course in Entrepreneurship. Proceedings. The NCIIA 9th Annual Meeting - March 17-19, San Diego.

Henry, C., Foss, L \& Ahl, H. 2013. Parallel Lines? A Thirty-Year Review Of Methodological Approaches In Gender And Entrepreneurship Research. Proceedings. ISBE Conference, Cardiff, UK.

Heriot, K. C., Simpson, L \& Stephenson, H. 2012. Small Business Institute Journal. 8 (1): 47-60.

Hickey, T \& Salas,P.2013. TheEntrepreneur'sBootcamp: A New Model For Teaching Web/Mobile Development \& Software Entrepreneurship. Available at : http://www.sigcse.org/sigcse2013/. Diunduh pada 10 Juli 2014.

Hindle, K. 2007. A grounded theory for teaching entrepreneurship using simulation games, Simulation \& Gaming. 33 (2): 236.

Holtsch, D \& Hoppe, M. 2007. ROXI Entrepreneurship Training Programme. Entrepreneurship Teaching \& Promotion at \& by Universities.University of Rostock \& HIERO (Germany). Available at: http:// interreg4c.eu/uploads/media/pdf/2_ Entrepreneurship_Teaching_Promotion at_and_by_Universities_BEPAR.pdf. Diunduh pada 29 Juni 2014.

Honig, B. 2004. Entrepreneurship Education: Toward a Model of Contingency-Based Business Planning. Academy of Management Learning \& Education. 3 (3): 258-273.

Huber,L.R.,Sloof,R\&Praag,M.V.2012.TheEffectof Early Entrepreneurship Education:Evidence from a Randomized Field Experiment. Proceedings. IZA Discussion Paper No. 6512, April 2012, Forschungsinstitut zur Zukunft der ArbeitInstitute for the Study of Labor, Bonn, Germany.

Idrees, R. N., Abbasi, A. S \& Waqas, M. 2013. Systematic Review of Literature on Workforce Diversity in Pakistan. Middle-East Journal of Scientific Research. 17 (6): 780-790.

Jarna, H., Anne, P. S \& Irma, V. V. 2006. Entrepreneurial-Directed Methods In Teaching Corporate Entrepreneurship For Phd Students. Proceedings. Institute for Small Business \& Entrepreneurship, 29th National Conference-Oct-Nov.
Kaijage, E \& Wheeler, D. 2013. Supporting Entrepreneurship Education in East Africa. The University of Nairobi School of Business \& Plymouth University Business School.

Kailer, N. 2006. Evaluation of Entrepreneurship Education at Universities, University of Linz, Institute for Entrepreneurship \& Organizational Development, Freistaedter Strasse, Linz.

Kalyani, B. P. R \& Kumar, D. M. 2011. Motivational factors, entrepreneurship \& education: Study with reference to women in SMEs. Far East Journal of Psychology \& Business. 3 (3): 14-35.

Karlsson, C., Johansson, B \& Stough, R. 2006. Entrepreneurship \& Dynamics in the Knowledge Economy. Routledge. USA.

Katz, J. A. 2003. The Chronology and Intellectual Trajectory of American Entrepreneurship Education. Journal of Business Venturing. 18 (2): 283-300.

Kefalas, P., Ketikidis, P.H. \& Ververidis, I.F. 2012. An entrepreneurial educational model for knowledge-based regional development through innovative learning practices. Proceedings.International Conference for Entrepreneurship, Innovation and Regional Development.

Kementrian Koordinator Bidang Kesejahteraan Rakyat. 2013. Minat Berwiraswasta Orang Indonesia Masih Rendah. Available at: http://2010kememkopmk.go.id/content/ menko-kesra-minat-berwirausaha-orangindonesia-masih-rendah. Diunduh pada 1 Juli 2014.

Kirketerp, A. L. 2011. Entrepreneurship didactics - the push method. Available at: http://ieeponline.com/ wp-content/ uploads/2013/11/Entrepreneurshipdidactics-\%E2\%80\%93-the-push-method. pdf. Diunduh pada 10 Juli 20014.

Kitchenham, B \& Charters, S. 2007. Guidelines for performing systematic literature review in software engineering. Technical Report. School of Computer Science and Mathematics, Keele University.

Klapper, R. 2008. Innovations in Entre preneurship Teaching: The Use of Repertory Grids Within the French Grande Ecole Context. International Journal of Euro-Mediterranean Studies. 1 (1): 114-133.

Kleemann, M. 2011. Insights in Entrepreneurship Education: Integrating Innovative Teaching Practices. Swedia: Jonkoping International Business School. 
Margo Purnomo / Dinamika Pendidikan Kewirausahaan: Pemetaan Sistematis Terhadap...

Klerk, J. K. S \& Dippenaar, A. 2003. Developing the next generation of potential entrepreneurs: co-operation between schools \& businesses?,South African Journal of Education. 23 (4): 319-322.

Koopman, R., Hammer, M \& Hakkert, A. 2014. Teaching Teachers in Effectual Entrepreneurship. Saxion University, University of Technology.

Kral, J. 2005. Case Study And Related Experiential Teaching Methods In Non-Case Environments: The Slovenia Experience. International Journal of Case Method Research o Application. 17 (3): 432-438.

Kuip, I \& Verheul, I. 2003. Early Development of Entrepreneurial Qualities: the Role of Initial Education. Available at : http://www. entrepreneurship-sme.eu/pdfez/ n200311. pdf. Diunduh pada 3 Juli 2014.

Kuratko, D. F. 2003. Entrepreneurship Education: Emerging Trends and Challenges For The 21st Century.Coleman Foundation White Paper SeriesFor The U.S. Association Of Small Business \& Entrepreneurship.

Kurnianto, B. S \& Putra, S. I. 2012. Menumbuh Kembangkan Minat Berwirausaha bagi Para Mahasiswa di Lingkungan Perguruan Tinggi. Prosiding. Seminar \& Konferensi Nasional Manajemen Bisnis. 26 Mei.

Lackéus, M., Lundqvist, M \& Middleton, K. W. 2013. How can Entrepreneurship Bridge Between Traditional\&ProgressiveEducation?.Proceedings. Conference pape rat ECSB Entrepreneurship cation Conference, Aarhus, Denmark on 2931 May.

Lakshmi, R \& Rangarajan, R. 2012. Women Entrepreneurs In India-A Perspective Study. International Journal of Social Sciences bo Interdisciplinary Research. 1 (5): 19-24.

Larsen, K. A \& Nagel, T. 2013. Entrepreneurship Education In Namibia: An Evaluation of the Implementation of Entrepreneurship Education and the role of NAMAS, The Namibia Association of Norway (NAMAS), Namibia.

Leino, J. S., Ruskovaara, E., Ikävalko, M., Mattila, J \& Rytkölä, T. 2009. Teachers' Reflections About Entrepreneurship Education, Lappeenranta University of Technology, Finland.

Levebre, M. R \& Collot, R. R. 2012. Achieving Legitimacy in Entrepreneurship Education: a case study. Journal of Enterprising Culture. 20 (4): 481-500.

Linan, F., 2004. Intention-based models of entrepreneurship education. Annual Report of University of Seville.
Lindner, J. 2012. Entrepreneurship Education between economic educational philosophy and key competence for lifelong learning. Initiative for Teaching Entrepreneurship (IFTE) \& the Impulse Centre for Entrepreneurship Education (eesi) of the Austrian Federal Ministry for Education, Arts \& Culture.

Lonappan, J. 2013. Pedagogical Innovations in Teaching Entrepreneurship.International Journal Of Scientific Research. 2 (2): 241243.

Lorz, M. 2012. The Impact of Entrepreneurship Education on Entrepreneurial Intention, Dissertation of the University of St. Gallen, School of Management, Economics, Law, Social Sciences \& International Affairs, Bamberg.

Lourenco, F \& Jones, O. 2006. Developing Entrepreneurship Education: Comparing Traditional \& Alternative Teaching Approaches. International Journal of Entrepreneurship Education. (4): 111-140.

Ludfiadi, R \& Rahmanto, M. I. 2011. Analisis Peran Pendidikan Kewirausahaan, Kepribadian, \&Lingkungan terhadap Minat Siswa SMK untuk Berwirausaha di Kota Bekasi. Jurnal Agribisnis \& Pegembangan Wilayah. 3 (1): 5666.

Lumpkin, G. T \& Lichtenstein, B. B. 2005. The role of organizational learning in the opportunityrecognition process. Entrepreneurship Theory \& Practice. 29 (4): 451-472.

Mäkimurto-Koivumaa, S. 2012. Effectuation In Embedded \& Enquiry-Based Entrepreneurship Education. Essays For Renewing Engineering Education At Kemi-Tornio University Of Applied Sciences. University Of Oulu, Oulu Business School, Department Of Management \& International Business.

Man, T. W. Y. 2006. Exploring the behavioural patterns of entrepreneurial learning: A competency approach. Education \& Training. 48 (5): 309-321.

Mansyur, M. 2013. Meningkatkan Minat Berwirausaha Melalui Program Pemagangan pada Dunia Industri bagi Mahasiswa IAIN Sunan Ampel Surabaya. Available at: http:// eprints.uinsby.ac.id/197/1/. Diunduh pada 30 Juni 2014.

Mansor, M \& Othman, N. 2011. Consulting-Based Entrepreneurship Education in Malaysian Higher Education Institutions. Proceedings. International Conference on Social Science \& Humanity, Singapore. 
Marques, L. A \& Albuquerque, C. 2012. Entrepreneurship Education \&The Development Of Young People Life Competencies And Skills, ACRN. Journal of Entrepreneurship Perspectives. 1 (2): 55-68.

Mauchi1, F. N., Karambakuwa, R. T., Gopo, R. N., Kosmas, N., Mangwende, $S$ \& Gombarume, F. B. 2011. Entrepreneurship education lessons: a case of Zimbabwean tertiary education institutions. Educational Research. 2 (7): 1306-1311.

Monteros, A. H. E. E \& Van Dorp, C. A. 2009. Methodology and Evaluation of Entrepreneurship Courses. The International Journal of Business Research and Management. 1 (3): 132-155.

Mopangga, H. 2014. Faktor Determinan Minat Wirausaha Mahasiswa Fakultas Ekonomi dan Bisnis Universitas Negeri Gorontalo. Trikonomika. 13 (1): 78-90.

Mulder, M., Lans, T., Verstegen, J., Biemans, H \& Meijer, Y. 2007. Competence development of entrepreneurs in innovative horticulture. Journal of Workplace Learning. 19 (1): 32-44.

Muller, S. 2013. Entrepreneurship of Regional. Development: On The Interplay. Between Agency \& Context. Available at: https://Pure. Au.Dk/Ws/Files/74825510/Phd Thesis Sabine_Mueller2. Pdf.Diunduh pada 3 Jūi 2014.

Muofhe, N.J \& Du Toit, W.F.2011.Entrepreneurial education's \& entrepreneurial role models' influence on career choice. SA Journal of HRM. 9 (1): 77-87.

Naderi, N., Rajaeepour, S \& Isfahani, A.R.N. 2013. Explaining The Role Of Education Quality In University Entrepreneurship: Based On Grounded Theory. Asian Journal of Management Sciences \& Education. 2 (4): 128135.

Nasrudin, N \& Othman, N. 2012. Evaluation of Polytechnic Entrepreneurship Programs in Malaysia, International Journal of Trade, Economics and Finance. 3 (5): 356-362.

National Strategies, Curricula \& Learning Outcomes. 2012. Entrepreneurship Education at School in Europe. Available at: http://eacea. ec.europa.eu/education/eurydice. Diunduh pada 8 Juli 2014.

Neck, H. M \& Greene, P. G. 2011. Entrepreneurship Education: Known Worlds \& New frontiers, Journal of Small Business Management. 49 (1): 55-70.
OECD. 2009. Evaluation of programmes concerning education for entrepreneurship: Report of the OECD Working Party on SMEs and Entrepreneurship. Available at: http:// ec.europa.eu/ enterprise/policies/sme/ promoting-entrepreneurship/educationtraining-entrepreneurship/ index_en.htm. Diunduh pada 3 Juli 2014.

Ogundele, O. J. K \& Abiola, J. O. 2006. Entrepreneurship And National Development: A Proposal For Evangelistic Agenda. European Scientific Journal. 8 (6): 134-148.

Onojetah, S. O \& Amiaya, A. O. 2013. Towards Implementing A Model of Multiple Contexts of Entrepreneurship Education/Studies Curriculum \& Instruction In Nigeria's Tertiary Institutions. International Journal of Education \& Research. 1 (9).

Onwurafor, E. U \& Enwelu, I. A. 2013. Rural Women Entrepreneurship in Agro-Food Processing In Enugu State, Nigeria. International Journal of Research in Applied, Natural and Social Sciences. 1 (2): 13-30.

Otuya, R., Kibas, P \& Otuya, J. 2013. A Proposed Approach for Teaching Entrepreneurship Education in Kenya. Journal of Education \& Practice. 4 (8): 204-209.

Painter, M. 2007. A Model For Entrepreneurship Training \& Management Skills Development For Sustainable Economic Growth. Education \& Training. IFMA. 291-299.

Patel, B \& Chavda, K. 2013. Rural Entrepreneurship in India: Challenge \& Problems. International Journal of Advance Research in Computer Science \& Management Studies. 1 (2): 28-37.

Petersen, K, Feldt, R., Mujtaba, S \& Mattsson, M. 2009. Systematic Mapping Studies in Software Engineering. Proceedings. $12^{\text {th }}$ International Conference onEvaluation \& Assessment in Software Engineering.

Pihie, Z. A. L \& Sani, A. S. A. 2009. Exploring The Entrepreneurial Mindset Of Students: Implication For Improvement Of Entrepreneurial Learning At University. The Journal of International Social Research. 2 (8): 340-345.

Pittaway, L \& Cope, J. 2006. Entrepreneurship Education: A Systematic Review of the Evidence. National Council for Graduate Entrepreneurship Working Paper 002/2006. Available at: http://www.ncge.org.uk/ research.php.Diunduh pada 1 Juli 2014. 
Margo Purnomo / Dinamika Pendidikan Kewirausahaan: Pemetaan Sistematis Terhadap...

Pittaway, L., Holt, R. \& Broad, J. 2008. Handbook of Research in Small Business \& Entrepreneurship : Synthesising Knowledge in Entrepreneurship Research: The Role of Systematic Literature Reviews, Center for Entrepreneurial Learning \& Leadership: Working Paper Series, Georgia Southern University.

Popta, G. 2002. Entrepreneurial Learning. SCALES-initiative (Scientific Analysis of Entrepreneurship \& SMEs). The SMEs \& Entrepreneurship Programme. The Netherlands' Ministry of Economic Affairs.

Priyanto, S. H. 2012. Entrepreneurial \& vocational learning in entrepreneurship education: Indonesian Non formal education perspective. Basic Research Journal of Business Management \& Accounts.1 (2): 30-36.

Purnomo, M. 2014. Alternatif Model Pendidikan Kewirausahaan Untuk Indonesia Timur. Prosiding.Seminar Nasional Indonesia Timur, Pusat Studi Kawasan Indonesia Timur (PUSKIT) Universitas Atma Jaya, Yogyakarta, 14 Juni.

Rae, D \& Carswell, M. 2000. Using a life-story approach in researching entrepreneurial learning: the development of a conceptual model and its implications in the design of learning experiences. Education+Training. 42 (4): 220-228.

Rae, D. 2003. Opportunity centred learning: an innovation in enterprise education? Education \& Training. 45 (8): 542-549.

Ramanigopal, C. S., Palaniappan, G \& Hemalatha, N. 2012, Need For Entrepreneurship Education In School Students. International Journal of Physical \& Social Sciences. 2 (3): 243-259.

Ras, P \& Pretorius, M. 2007. An Entrepreneurial Education Model For The Namibian Higher Education System. Acta Commercii. 3 (3): 327-336.

Rasmussena, E. A \& Sørheim, R. 2006. Action-based entrepreneurship education. Technovation. 26 (1): 185-194.

Rodríguez, F. J. G., Soto, E. G \& Rosa, I. R. 2012. New Methods in University Entrepreneurship Education: A Multidisciplinary Teams Approach. Creative Education. 3 (Special Issue): 878-883.

Romo, M. J., Romero, D \& Molina, A. 2013. Entrepreneurship-based Learning: A New Teaching Technique for ActiveLearning Oriented to Multi-disciplinary Groups. Proceedings. Eleventh LACCEI Latin
American and Caribbean Conference for Engineering and Technology, August 14 - 16, 2013 Cancun, Mexico.

Rosiński, J \& Klich, J. 2007. Teaching Negotiation Skills: University Model Based on Entrepreneurial Experience. Entrepreneurship Teaching \& Promotion at \& by Universities.Jagiellonian University, Kraków, CITTRU (Poland).

Sarasvathy, S. D \& Venkataraman, S. 2011. Entrepreneurship as method: open questions for an entrepreneurial future. Entrepreneurship Theory \& Practice. (35): 113-135.

Seno, V. H. 2010. Pemodelan Motivasi Lulusan Perguruan Tinggi Menjadi Wirausaha Global pada Sektor Usaha Jasa di Wilayah Kota Depok. Available at: http: / / publication.gunadharma.ac.id/ bitstream/123456789/3483/1. Diunduh pada 1 Juli 2014.

Shaikh, A.B., Sarim, M., Raffat, S.K., Siddiq, M., Nadeem, A. \& Ahsan, K. 2014.Integrating Entrepreneurship into the Teaching of IT.Research Journal of Recent Sciences.3 (6):112-115.

Sidhu, I., Singer, K., Suoranta, M \& Johnsson, C. 2014.Introducing Berkeley Method of Entrepreneurship-a game-based teaching approach. Proceedings. The $74^{\text {th }}$ Annual Meeting of The Academia of Management.

Smith, K \& Petersen, J. L. 2006. What Is Educational Entrepreneurship?, Educational Entrepreneurship: Realities, Challenges, Possibilities. Available at: http: / / gs eweb.harvard.edu/hepg/ educationalentrepreneurship.html. Diunduh pada 3 Juli 2014.

Soare, E. 2008, Entrepreneurship EducationInnovative Way Of Curricular Restructuring, Lucrări Ştiințifice - Vol. 51, seria Agronomie, Universitatea de Ştiințe Agricole şi Medicină Veterinară Iaşi.

Streeter, D. H. \& Jaquette, J.P. 2004. University-wide Entrepreneurship Education: Alternative Models \& Current Trends, Southern Rural Sociology. 20 (2): 44-71.

Stylman, S.P. \& Hannula, H. 2007.Competence-based Entrepreneurship Model. Entrepreneurship Teaching \& Promotion at \& by Universities. HAMK University of Applied Sciences (Finland).

Sudarmanto, R. G. 2011. Pengembangan Kewirausahaan dan Daya Saing Bangsa Melalui Pendidikan Karakter.Dies Natalis ke 46 Universitas Lampung. Available at: 
http://staff.unila.ac.id/radengunawan/ files/2011/09/Pendidikan-KarakterKewirausahaan-dan-Daya-Saing.pdf. Diunduh pada 30 Juni 2014.

Suonpaa, M. 2013. Constructing an Opportunity Centred Collaborative Learning Model through and for Entrepreneurship. Jyväskylä Studies In Business And Economics, University Of Jyväskylä.

Susilowati, T. 2013. Pengembangan Pendidikan Kewirausahaan dalam Upaya Menumbuhkan Budaya Wirausaha pada Siswa Sekolah Menengah Atas (SMA) di Kabupaten Karanganyar. Jurnal Kewirausahaan dan Bisnis. 7 (12).

Tan, S. S \& Ng, C. K. F. 2006. A problem-based learning approach to entrepreneurship education. Education \& Training. 48 (6): 416428.

Tasnim, R \& Yahya, S. 2013. Playing Entrepreneurship: Can Games Make a Difference?. Entrepreneurial Practice Review. 2 (4): 4-16.

Taylor, D. W \& Thorpe, R. 2004. Entrepreneurial learning: a process of co-participation. Journal of Small Business \& Enterprise Development. 11 (2): 203-211.

Taylor, D. W., Jones, O \& Boles, K. 2004. Building social capital through action learning: An insight into the entrepreneur. Education of Training. 46 (4): 226-235.

Teece, D. J. 2012. Dynamic Capabilities: Routines versus Entrepreneurial Action. Journal of Management Studies. 49 (8): 1395-140.

Tervonen, P. 2007. Business Planning 3 ECTS (Business Plan): virtual based web - course. Entrepreneurship Teaching \& Promotion at \& by Universities. Kajaani University of Applied Sciences (Finland)

Thornberry, N. E. 2002. Corporate entrepreneurship:teaching managers to be entrepreneurs. Journal of Management Development. 22 (4): 329-344.

Thorpe, R., Holt, R., Macpherson, A \& Pittaway, L. 2005. Knowledge within small \& medium sized firms: a systematic review of the evidence. International Journal of Management Reviews. 7 (4): 257-281.
Todorov, K \& Papazov, E. 2009. A successful model of entrepreneurship education \& training in transition countries: the example of Bulgaria. Available at: http://fbm.uni-ruse.bg/jei/ Issue-9-2009/14.pdf. Diunduh pada 3 Juli 2014.

Venesaar, U \& Kolbre, E. 2007. A Case of Teaching Business Planning.Entrepreneurship Teaching \& Promotion at and by Universities.Tallinn University of Technology (Estonia). Tallinn School of Economics and Business Administration

von Graevenitz, G., Harhoff, D \& Weber, R. 2010. The effects of entrepreneurship education. Journal of Economic Behavior \& Organization. $76(1): 90-112$.

Weber, R., von Graevenitz, G \& Harhoff, D. 2009. The Effects of Entrepreneurship Education. Discussion Paper No. 269, Governance \&The Efficiency System.

Wee, K. N. L. 2004. Problem-based learning approach in Entrepreneurship Education: promoting authentic entrepreneurial learning, International Journal Technology Management. 28 (7).

Western Economic Diversification Canada. 2011. Evaluation of Entrepreneurs with Disabilities Program. Available at : http://www.wd.gc. ca/images/cont/13314a-eng.pdf. Diunduh pada 3 Juli 2014.

White, R., Hertz, G \& D'Souza, R. 2011. Teaching a Craft-Enhancing Entrepreneurship Pedagogy. Small Business Institute Journal. 7 (2): 1-14.

Williamson, N., Beadle, S \& Charalambous, S. 2013. Enterprise Education Impact In Higher Education And Further Education, Department for Business, Innovation \& Skills, Victoria Street London.

Woolthuis, R. K., Hooimeijer, F., Bossink, B., Mulder, G \& Brouwer, J. 2013. Institutional entrepreneurship in sustainable urban development: Dutch successes as inspiration for transformation. Journal of Cleaner Production. (50): 91-100.

Zhou, M \& Xu, H. 2012. A Review of Entrepreneurship Education for College Students in China, Administrative Sciences. (2): 82-98. 